\title{
コワーキングスペースの利用実態と施設運営に関する研究
}

\section{施設特性の把握と利用者の意識・行動、運営者の運営方針の関連に着目して \\ STUDY ON ACTUAL USAGE AND FACILITY MANAGEMENT OF COWORKING SPACE}

Understanding facility characteristics and focusing on the relationship between user awareness / behavior and operator management policy

\section{今和泉 拓 ${ }^{* 1}$, 佐 藤 宏 ${ }^{* 2}$, 生田京子*3, 恒川和 久*4 \\ Taku IMAIZUMI, Hiroshi SATO, Kyoko IKUTA and Kazuhisa TSUNEKAWA}

\begin{abstract}
This study targets coworking spaces that are increasing due to changes in social conditions in recent years. Through a questionnaire survey of domestic coworking spaces, we grasped the basic data of the facility characteristics. We also classified coworking spaces and extracted their characteristics, and clarified that there are characteristics in the response tendency depending on the scale and land price. Furthermore, through behavior observation surveys and interview surveys with users and interview surveys with operators, it was clarified that the awareness and behavior of users and the facility management policy of operators are interrelated.
\end{abstract}

Keywords : Coworking space, Facility characteristics, User behavior, User awareness, Management policy コワーキングスペース，施設特性，利用者の行動，利用者意識，運営方針

\section{1. 研究の背景と目的}

\section{1-1. はじめに}

近年、ICT 環境の発展や、働き方改革の潮流を背景に、場所や組 織の枠に囚われない働き手が増加しており、その働き手を支える環 境や場所のニーズも高まっている。そのニーズに応えるために、シェ アードオフィスやコワーキングスペース ( 以下 CWS) といった $1 つ$ の空間を複数の企業や個人が共有するスペースが増加している。

特にCWS は各文献の定義（Table1）をまとめると、「単なる働く場 所の共有に留まらず、交流を行うことにより知恵や情報を共有し価 值を創出することを重視している空間」と言え、その点において、 シェアードオフィスなどとの差別化がなされている。

\section{1-2. 既往研究}

シェアードオフィスを対象にした研究では、納村ら ${ }^{12)}$ による、 利用者の観察調查から利用者の共用スペースでの活動タイプの分類 や、固定テーブルから可動テーブルへの変更に伴う利用状況の変化 を論じているものがあるが、シェアードオフィスという特性上、作 業環境に主眼を置いたものである。

CWS を対象にしたものでは、阿部ら ${ }^{344)}$ が経済学の研究として、 アンケート調查により、運営実態を施設、運営組織、戦略、活動、

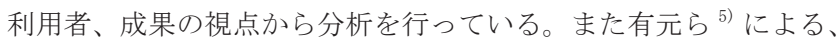
CWS の施設タイプによる類型化を行い、利用者の日誌調查及びイン
タビュー調査により、利用者の多様な働き方について考察を行った もの、渡辺ら ${ }^{6)}$ によ、利用者及び運営者に対するインタビュー 調査により CWS の基礎的な実態と多角的分析を行ったもの、辻井ら 7)による、全国の CWS へのアンケート調查による傾向及び変化を記 し、企業に属する人々へのアンケート・インタビュー調査により、 企業における CWS の活用における価值と意義を整理したものなどが ある。地域を絞ったものでは、古内ら ${ }^{8)}$ による一都三県を対象に 運営実態の調査と共に、法人設立や交流会の開催などの成果を調査 したもの、三木ら ${ }^{9)}$ による地方の CWS を対象に地域の交流拠点と しての可能性に着目したもの、松村ら ${ }^{10) 11)}$ による地方のCWS の運 営課題について述べたものがある。

\section{1-3. 研究の目的}

上記のように既往研究では、全国での CWS の傾向を記したものや 地域を絞った上で分析を行ったものがあるが、類型化を行った上で 特徴を述べたものはない。また、利用者や運営者に焦点を当てたも のはあるが、利用者の意識と行動の関連を述べたもの、利用状況が 運営者の施設運営方針に与える影響について述べたものはない。

そこで本研究では、アンケート調查により CWS の施設特性の把握 し、分類および特徴の抽出を行うとともに、利用者の行動観察調查. インタビュー調査、及び運営者へのインタビュー調査により、利用 者の意識・行動と、運営者の施設運営方針との関連を調查すること
名古屋大学大学院環境学研究科 博士後期課程

(侏シーラカンスアンドアソシエイツ

名城大学理工学部建築学科 教授・博士 (工学)

名古屋大学大学院工学研究科 教授・博士 (工学)
Grad. Student, Graduate School of Environmental Studies, Nagoya Univ. Coelacanth and Associates Co., Ltd.

Prof., Dept. of Architecture, Science and Engineering, Meijo Univ., Dr.Eng.

Prof., Graduate School of Engineering, Nagoya Univ., Dr.Eng. 
で、施設計画者・運営者が CWS を計画・運営する際の基礎的資料と することを目的としている。

\section{2. 研究方法}

\section{2-1. 研究の対象}

前述のとおり、CWS を「単なる働く場所の共有に留まらず、交流 を行うことにより知恵や情報を共有し価值を創出することを重視し ている空間」と言えるが、本研究における調查対象としては、一般 にCWS として認識されている空間のうち、利用者が管理者に許可を 得て、共用使用できる空間とした。

\section{2-2. 研究の流れと調査概要 (Table2)}

3 章では、CWS のキュレーションサイト注3) を参考に 2019 年 6 月 時点で掲載されている全ての CWS 郵送アンケートを実施し（対象 数 $738^{\text {注 }}$ )、回答数 94 、回答率約 $13 \%$ 、回答期間 2019 年 6 月～10月 )、 施設、運営、計画、利用者に関する施設特性の把握を行い、CWS を類型化し、類型ごとの特徵を捉える。

4 章以降は、3 章の類型からある類型を取り上げ、その中から選 定した 3 施設において、利用者の行動観察調查及びインタビュー調 查、運営者へのインタビュー調查を実施し（2019 年 10 月〜 12 月）、 その結果を分析する。

4 章では行動観察調查を基に、座席での作業内容、交流の有無な どを把握する。更に、滞在時間や移動先なども同時に把握すること で、CWS 内における利用者の行動実態を明らかにする。

5 章では利用者へのインタビュー調查を基に、利用者属性（事務 所の有無、利用目的、作業内容など）と、CWS の選択理由や座席の 選択理由、一日の活動内容、交流の有無などについて把握し、4 章 と合わせ利用者の CWS における場所の選択・構築のプロセスについ て考察を行う。

6 章では運営者へのインタビュー調查を基に、CWS 内での役割や 立場、利用者に対しての考えや施設運営方針に関する言及について 分析を行い、レイアウトやシステム更新との関連を考察する。

\section{3. 国内 CWS の傾向（施設、運営、計画、利用者）の把握と分類}

\section{3-1. アンケート内容}

施設、運営、計画、利用者について、Table3に示寸質問を行った（対 象数 738、回答数 94)。選択式 - 単一回答のものは SA、選択式・複 数回答可のものはMA、自由回答欄はFA と記載している。尚、質問 により無回答の項目があったため、N 值が異なる場合がある。

\section{3-2. 単純集計による全体像の把握}

\section{1) 建物状況}

入居している建物は「借りている」が $73.4 \%$ 、「所有している」 は26.6\%であった (Fig. 1)。CWS の運営の範囲は「建物の一部」で 運営している CWS が 96.8\%、建物の全体」が 3.2\%であった (Fig. 2)。 工事状況に関しては「改修」が $86.2 \%$ と大半を占めていた (Fig. 3)。 従前用途は「通常業務オフィス」が $56.8 \%$ と最も多く、次に「店舗」 の $25.9 \%$ であった。「その他」の回答は「専門学校」「大学施設」「保 育園」「映画館」などである (Fig. 4)。このことから、CWS は建物 の一部を改修・転用、または空きテナントを活用していることが多 いと考えられる。また内装工事は、 $40.4 \%$ が新規施工、 $20.2 \%$ が従 前のまま、39. $4 \%$ が新規施工十一部従前のままであった (Fig. 5)。
Table1 Definition of coworking space in prior literatures

\begin{tabular}{|c|c|}
\hline 引用元 & 内容 \\
\hline $\begin{array}{l}\text { 宇田忠司 }{ }^{12)} \\
\text { Uda Tadashi }\end{array}$ & 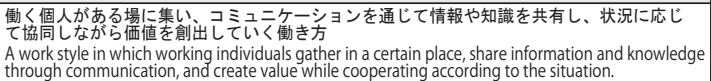 \\
\hline $\begin{array}{ll}\text { 伊藤富雄 } & 13 \text { ) } \\
\text { Ito Tomio }\end{array}$ & 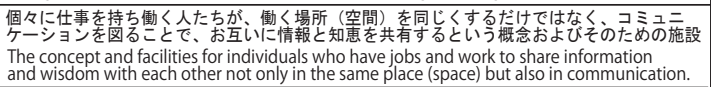 \\
\hline $\begin{array}{lr}\text { 小林ら } & 14) \\
\text { Kobayashi et al. }\end{array}$ & 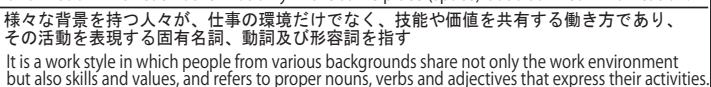 \\
\hline 15) & 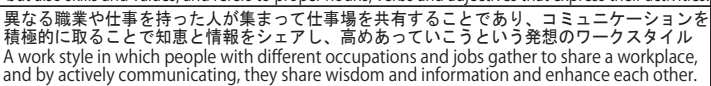 \\
\hline $\begin{array}{r}\text { 注 1) } \\
\text { Coworking Wiki }\end{array}$ & 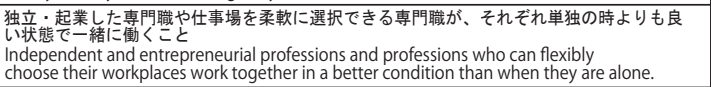 \\
\hline $\begin{array}{l}\text { コワーキング } \\
\text { コ注 } \\
\text { 協同組合 } \\
\text { (2019䦎覧) }\end{array}$ & 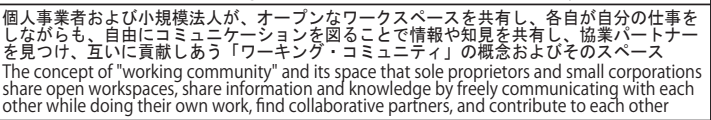 \\
\hline
\end{tabular}

Table2 Summary of survey

\begin{tabular}{|c|c|c|c|c|c|c|c|c|}
\hline \multirow{2}{*}{\begin{tabular}{|l} 
A) Questionnaire survey: \\
by mail \\
Survey period \\
$06 / 2019 \sim 10 / 2019$
\end{tabular}} & \multirow{2}{*}{\multicolumn{6}{|c|}{$\begin{array}{l}\text { [Contents of question] } \\
\text { About facility outline, operation, facility planning, users } \\
\text { Target selection method] } \\
\text { All cases posted on the CWS curation site as of June } 2019\end{array}$}} & \multicolumn{2}{|c|}{$\begin{array}{l}\text { [Number of distributions] }: 853 \\
\text { [Unanswerable cases] }: 115 \\
\text { [Number of actual cases] }: 738\end{array}$} \\
\hline & & & & & & & sponse ratel & $: 13 \%(94)$ \\
\hline \multirow[t]{5}{*}{$\begin{array}{l}\text { B) Behavior observation: } \\
\text { survey for users } \\
\text { Survey period } \\
10 / 2019 \sim 11 / 2019\end{array}$} & \multicolumn{8}{|c|}{$\begin{array}{l}\text { [Target selection method] } \\
\text { Extract } 3 \text { cases from specific clusters (CL5) in Chapter } 3 \\
\text { [Recording conditions] } \\
\text { Movement within the facility or change in usage content }\end{array}$} \\
\hline & \multicolumn{4}{|c|}{\begin{tabular}{|l|l|l|l|} 
Case No. Survey date & Survey time \\
\end{tabular}} & \multicolumn{4}{|c|}{ Number of investigators Actual number of users } \\
\hline & Case1 & \multicolumn{2}{|c|}{ Nov.08 } & 9:00 22:00 (13hour) & \multicolumn{2}{|r|}{2} & \multicolumn{2}{|r|}{24} \\
\hline & Case2 & \multicolumn{2}{|c|}{ Nov.01 } & 9:00 20:00 (11hour) & \multicolumn{2}{|r|}{3} & \multicolumn{2}{|r|}{14} \\
\hline & Case3 & \multicolumn{3}{|c|}{\begin{tabular}{l|l|} 
Oct.23 & $10: 00 \sim 19: 00$ (9hour) \\
\end{tabular}} & \multicolumn{2}{|r|}{2} & \multicolumn{2}{|r|}{14} \\
\hline \multirow{8}{*}{$\begin{array}{l}\text { C) Interview with users } \\
\text { Survey period } \\
10 / 2019 \sim 12 / 2019\end{array}$} & \multicolumn{8}{|c|}{$\begin{array}{l}\text { [Contents of question] Age, gender, occupation, reason for using CWS, } \\
\text { reason for choosing CWS, reason for choosing a seat, etc. }\end{array}$} \\
\hline & $\begin{array}{l}\text { Case } \\
\text { No. }\end{array}$ & \multicolumn{2}{|c|}{ Survey date } & Survey time & & $\begin{array}{l}\text { Number of } \\
\text { investigators }\end{array}$ & \begin{tabular}{|l|l|}
$\begin{array}{l}\text { Number of } \\
\text { respondents }\end{array}$ \\
\end{tabular} & $\begin{array}{l}\text { Actual number } \\
\text { of users }\end{array}$ \\
\hline & \multirow{2}{*}{$\begin{array}{l}\text { Case } \\
1\end{array}$} & \multirow{2}{*}{$\begin{array}{l}\text { Nov.06 } \\
\text { Nov.07 } \\
\text { Dec.14 }\end{array}$} & $\begin{array}{l}\text { Weekdays } \\
\text { Weekdays }\end{array}$ & \begin{tabular}{l|l}
$y s$ & $9: 00 \sim 22: 00(13 \mathrm{hh}$
\end{tabular} & hour) & \multirow{2}{*}{1} & 12 & 24 \\
\hline & & & Holiday & 9:00 20:00 (11h) & & & 10 & 18 \\
\hline & \multirow{3}{*}{$\begin{array}{l}\text { Case } \\
2\end{array}$} & \multicolumn{2}{|c|}{$\begin{array}{ll}\text { Oct.30 } & \text { Weekdays } \\
\text { Oct } 31 & \text { Weekdays }\end{array}$} & \multirow{3}{*}{ 9:00 20:00 (11hou } & \multirow{3}{*}{\multicolumn{2}{|c|}{1}} & \multirow{2}{*}{12} & \multirow{2}{*}{16} \\
\hline & & \multirow{2}{*}{\multicolumn{2}{|c|}{$\begin{array}{ll}\text { Dec.21 Holiday } \\
\text { Dec.22 Holiday }\end{array}$}} & & & & & \\
\hline & & & & & & & 7 & 7 \\
\hline & $3^{\text {Case }}$ & \begin{tabular}{|l|} 
Oct. 24 \\
Oct. 25 \\
\end{tabular} & $\begin{array}{l}\text { Weekdays } \\
\text { Weekdays }\end{array}$ & \begin{tabular}{l|l} 
ys & 10:00 19:00 (9he \\
$y s$ &
\end{tabular} & & 1 & 9 & 12 \\
\hline $\begin{array}{l}\text { D) Interview with } \\
\text { the operator }\end{array}$ & 【Conte & nts of $c$ & question】 & $\begin{array}{l}\text { Position o } \\
\text { of operatic }\end{array}$ & ser & $\begin{array}{l}\text { erator in the o } \\
\text { of creating a }\end{array}$ & $\begin{array}{l}\text { organization / E } \\
\text { place /etc. }\end{array}$ & round \\
\hline & $\begin{array}{l}\text { Case } \\
\text { No. }\end{array}$ & Surve & ey date & Survey time & & \begin{tabular}{|l|}
$\begin{array}{l}\text { Number of } \\
\text { investigators }\end{array}$ \\
\end{tabular} & \begin{tabular}{|l|} 
Number of \\
respondents \\
\end{tabular} & \begin{tabular}{|l|} 
Number of \\
characters
\end{tabular} \\
\hline beriod & Case & 1 Nov. 0 & \begin{tabular}{l|l}
6,2019 & 1 \\
6
\end{tabular} & 13:00 13:25(25mi & & & 1 & 3240 \\
\hline & & & 31,2019 & & & 1 & 2 & 5142 \\
\hline
\end{tabular}

Table3 List of Questionnaire

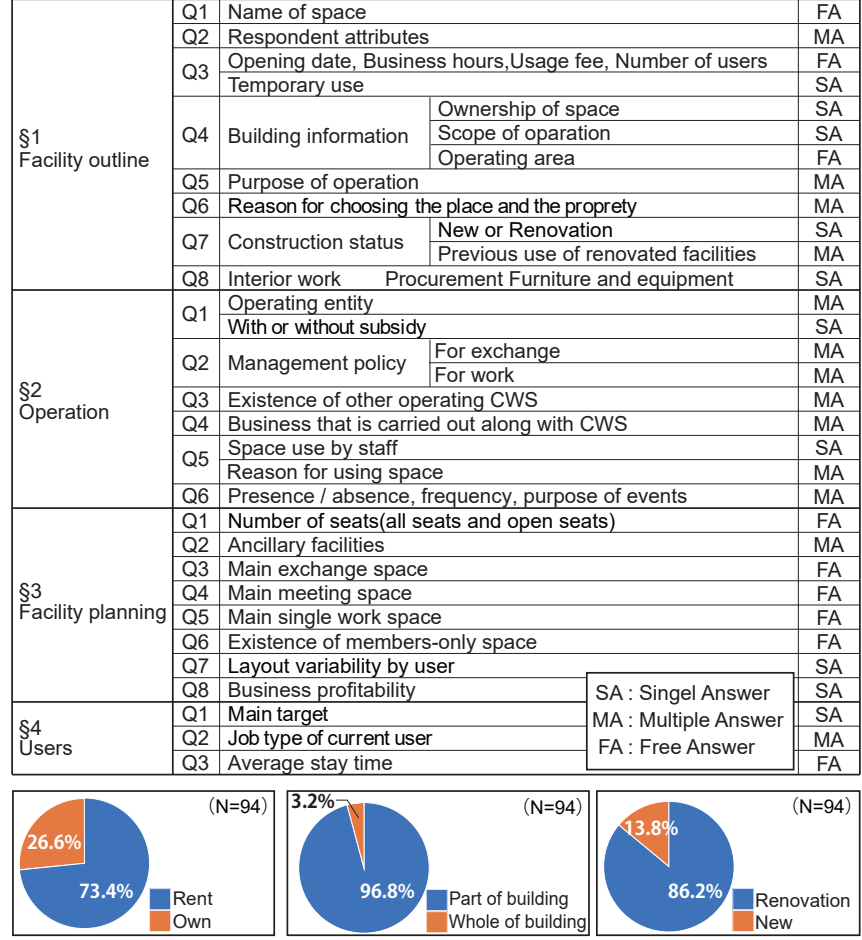

Fig.1 Ownership of space Fig.2 Scope of operation Fig.3 Construction status 


\section{2) 運営主体 (Fig.6) と補助金の活用 (Fig.7)}

CWS の運営主体で最も多いのは「企業」の $68.1 \%$ 、次に多いのは 「個人」の $16.0 \%$ であり、「NPO」7.4\%や、「行政」3.2\% といった回 答もあった。尚「その他」には「一般財団法人」「任意団体」「LLP」 「共同企業体」がある。また、補助金の活用については、「活用して いる」が 19.1\%、「活用していない」が 80.9\% であった。

\section{3) 席数 (Fig.8)}

不特定多数の人が利用でき交流が見込まれるオープン席注5) の席 数 $\mathrm{n}$ は「 $\mathrm{n} \leqq 20 」 の$ 施設が 33 件と最も多く、次に多いのは「20 $<\mathrm{n} \leqq 40 」 の 31$ 件、「60<n」の施設は 7 件であった。また、運 営全体の席数注 6$)$ の合計は 60 席以下に集中しており、「60<n」の 施設は 18 件であった注7)

\section{4) 路線価}

各施設の所在地の路線価注 8 を求めた。最低は 0.4 万円 $/ \mathrm{m}^{2}$ (沖 縄県島尻郡)、最高は 1780 万円 / $\mathrm{m}^{2}$ (東京都千代田区) あり、特 定の地域によらず分布していた。

\section{5) 運営の目的 (Fig.9)}

「起業家やスタートアップ企業のため」に当てはまった施設 が 74.5\%(70 件) と最も多く、次に「異業種間の交流を促すた め」の $71.3 \%$ (67 件) が続く。一方「経済的な利益を得るため」は 30. 9\%(29 件) であることから、CWS は採算性よりも、起業に関する サポートや異業種間の交流の促進を重視していると考えられる。

\section{6) 立地と物件の選定理由 (Fig.10)}

「交通の便が良いので」に当てはまった施設が $48.6 \%$ (44 件) と 最も多く、「地域活性化のため」の $43.6 \%$ (41 件)、「周辺にコワー キングスペースが少ないので」の 42. 6\%(40 件) と続く。

\section{7) 交流に関する運営方針 (Fig.11)}

重視する交流のレベルについて、低い順に「利用者どうしで日常 的に挨拶が交わされる」「利用者どうしで仕事上の知識、技術を共有、 交換する」「利用者どうしで共に仕事を遂行する」の 3 段階で質問 を行った。高いレベルが該当した場合は低いレベルの回答も該当す るとして補正を行い集計を行った結果、「利用者どうしで日常的に 挨拶が交わされることを重視している」施設が 83.0\%(78 件 ) に上 り、多くの施設で交流を重視していることがわかる。また「利用者 どうしで仕事上の知識、技術を共有、交換することを重視してい る」 69.1\% (65 件)「利用者どうしで共に仕事を遂行する」43. 6\%(41 件）という、CWS 特有の交流による価值の創出を重視する施設があ る。利用者層については「同じ職業や分野」 $7.4 \%$ (7 件 ) よりも「多 様な職業や分野の利用者が使うことを重視している」76.6\%(72 件 ) 施設が多数であった。また、「地域住民の交流拠点となる」に当て はまった施設は $35.1 \%$ (33 件) と少なくない。

8) CWS と一体で行っている事業 (Fig.12)

77. 7\%(73 件) で一体で行っている事業があり、内訳は「貸し 会議室の運営」で 61.6\%(45 件)、「他事業の事務所の運営」で 47. 9\% (35 件)、「レンタルオフィスの運営」は 39.7\%(29 件)、「事 業マッチングサービス」が $17.8 \%$ (13 件)、「カフェの運営」の 9. $6 \%$ (7 件)、「宿泊施設の運営」の $4.1 \%$ (3 件 ) であった。

\section{9）主なターゲット (Fig.13) と現在の利用者像 (Fig.14)}

利用者の主なターゲットは「個人」が $33.0 \%$ 、「企業」が $6.4 \%$ 、「両方」 が $60.6 \%$ であった。また、現在の CWS の利用者像に当てはまるもの
についての回答では、最も多く当てはまった利用者像は 73. 4\%(69 件) の「IT 系」で、次に多いのは 62.8\%(59 件) の「デザイン系」、 $52.1 \%$ (49 件) の「対人サービス系」と続く。「その他」の回答は「ま ちづくり系」「スポーツ事業」「音響系」「観光系」といった内容で、 回答に偏りはあるものの、利用者は多岐にわたることが分かった。

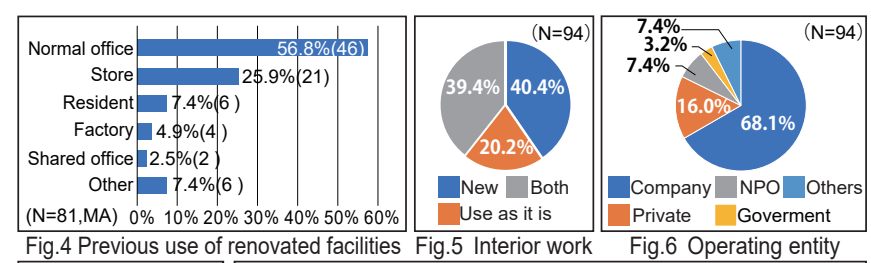

Fig.4 Previous use of renovated facilities Fig.5 Interior work Fig.6 Operating entity
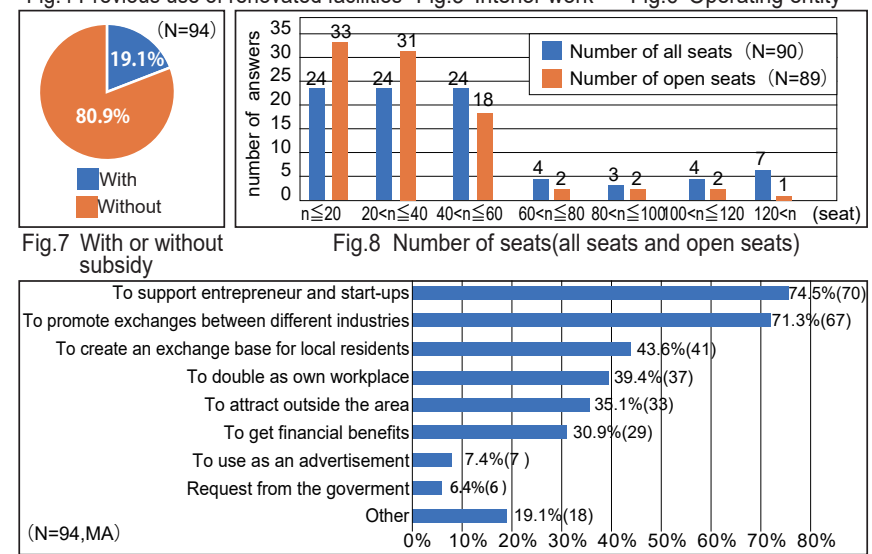

Fig.9 Purpose of operation

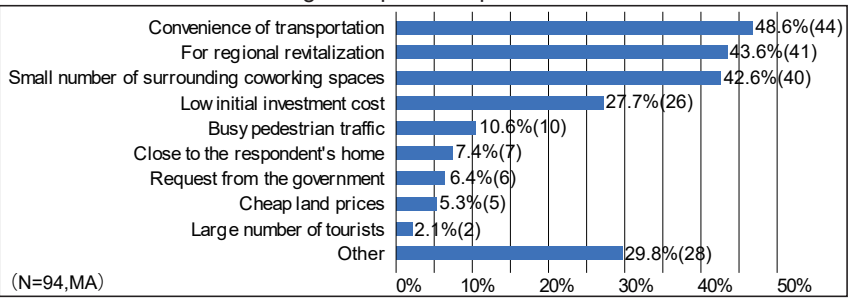

$\begin{array}{ccccc}0 \% & 10 \% & 20 \% & 30 \% & 40 \%\end{array}$

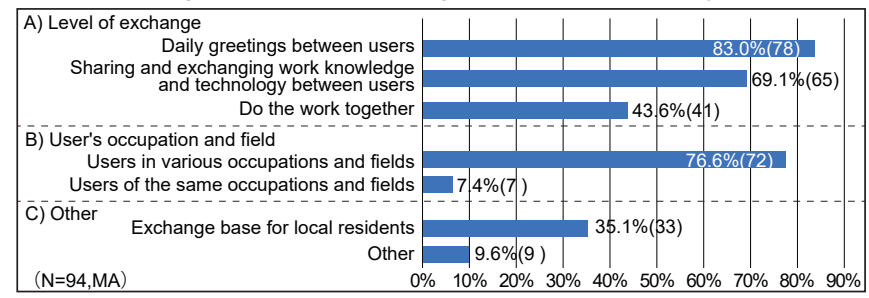

Fig.11 Management policy for exchange

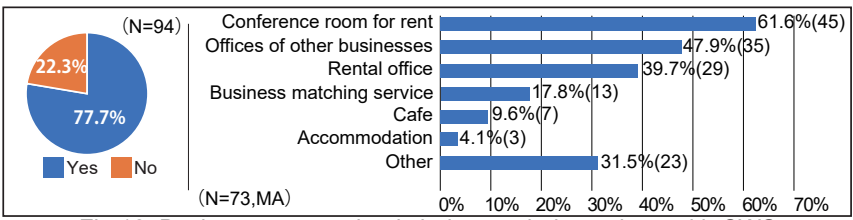

Fig.12 Business content that is being carried out along with CWS

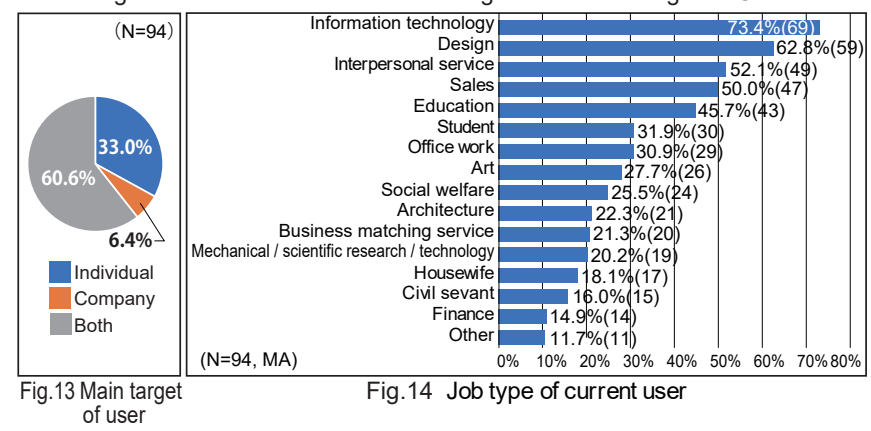




\section{3-3. 相関分析による傾向の分析}

\section{1) 相関係数の算出と有意性の判定}

各回答の関連性を調べるため、統計解析ソフト注9)を用い、相 関係数及び有意確率（ $\mathrm{p}$ 值）を求め有意性の判定を行った結果を Table4 〜 6 に示す。各項目の值は相関係数を示し、 $\mathrm{p}<0.05$ で有 意性があるとし淡赤色で示し、該当項目について考察を行う注 ${ }^{10}$ 。

\section{2) 運営目的と交流に関する運営方針の相関 (Table4)}

運営した目的の「起業家やスタートアップ企業のサポートのため」 と交流に関する運営方針の「多様な職種や分野の利用者が使う」の 間に弱い相関 (0.253) がみられた。一方で、運営した目的の「広告 として活用するため」と、交流に関する運営方針の「同じ職種や分 野の利用者が使う」の間に弱い相関 (0.383) がみられた。このこと から、運営目的が起業家やスタートアップ起業のサポートの場合は 多様な利用者をターゲットにしているのに対し、広告として活用す る場合にはターゲットが絞られていると推測できる。また、運営し た目的の「経済的な利益を得るため」と「利用者どうしで日常的に 挨拶が交わされる」の間に弱い負の相関 $(-0.249)$ がみられたこと から、利益を考慮する施設では利用者同士の交流をさほど重視して いないと考えられる。

\section{3) 運営目的と立地に関する開設理由の相関 (Table5)}

運営した目的と立地に関する開設した理由との相関分析の結果 を示す。「地域外から人を呼び込むため」と「周辺にCWS が少な い」に弱い相関があり (0.223)、「地域活性化のため」と「地域外 から人を呼び込むため」（0.342）、地域住民の交流拠点を作るため」 (0.394) に弱い相関が見られた。つまり、CWS を開設し地域外から の人を呼び込み、地域内にとっては交流拠点として機能させること で地域活性化に繋げようとしている、と考えられる。また、CWS が 広告として活用される場合もあり、旅行客が多いような場所が選 ばれる傾向（0.520）があり、また自身の仕事場を兼ねるために運 営される場合には、回答者の自宅から近い場所に開設される傾向 (0.269) があった。

\section{4）立地に関する開設理由と CWS と一体で行っている事業 (Table6)}

立地に関する開設した理由と CWS と一体で行っている事業内容と の相関分析の結果を示す。旅行客が多い立地ほど、カフェを一体と して運営している傾向（0.520）があった。また、地域活性化のた めに開設しているCWS には貸し会議室の運営（0.274）や他事業の 運営（0.254）をしている傾向があった。

\section{3-4. クラスター分析による類型化と各クラスターの特徵の分析 1) クラスター分析}

施設規模の指標となる「運営全体の席数」と、地域特性の指標 となる「路線価」を変数としてクラスター分析注 ${ }^{11}{ }^{\text {注 }}{ }^{12)}$ を行い、5 つのクラスターを生成し、それぞれの特徴から「(1)小規模低地価」 「(2)小規模高地価」「(3)中規模中地価」「(4)大規模低地価」「(5)大規 模高地価」と命名した ${ }^{13)}$ 。各クラスターの件数、重心と分布を Table7、Fig. 15 に示す。

\section{2) 各クラスターの特徴の抽出}

クラスターごとのアンケート集計結果に対し調整済み残差 $\mathrm{d}^{\text {注 }}{ }^{14)}$ を算出した結果を Table8 に示寸。有意確率 $\mathrm{p}<0.05$ にあたる $|\mathrm{d}|$ $>1.96$ の項目を淡赤色としその項目を見ると、クラスターごとで 回答傾向に特徵があることが分かる。注目すべき点を以下に示す。
Table4 Correlation coefficient of each answer

\begin{tabular}{|c|c|c|c|c|c|c|c|}
\hline \multirow{2}{*}{\multicolumn{2}{|c|}{$\square \mathrm{P}<0.05$}} & \multicolumn{6}{|c|}{ Management policy for exchange } \\
\hline & & $\begin{array}{l}\text { Daily greetings } \\
\text { between users }\end{array}$ & $\begin{array}{l}\text { Sharing and } \\
\text { exchanging work } \\
\text { knowiedge and } \\
\text { technology } \\
\text { between users }\end{array}$ & $\begin{array}{l}\text { Do the work } \\
\text { together }\end{array}$ & $\begin{array}{l}\text { Users in various } \\
\text { occupations and } \\
\text { fields }\end{array}$ & $\begin{array}{l}\text { Users of the } \\
\text { same occupa- } \\
\text { tion or field }\end{array}$ & $\begin{array}{l}\text { Exchange base } \\
\text { for local } \\
\text { residents }\end{array}$ \\
\hline \multirow{8}{*}{ 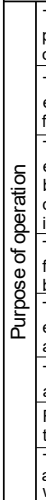 } & \begin{tabular}{|l|} 
To attract \\
people from \\
outside the area
\end{tabular} & 0.096 & 0.009 & 0.072 & 0.038 & 0.131 & 0.440 \\
\hline & $\begin{array}{l}\text { To create an } \\
\text { exchange base } \\
\text { for local residents }\end{array}$ & 0.113 & -0.016 & 0.178 & 0.182 & 0.159 & 0.656 \\
\hline & \begin{tabular}{|l|} 
To promote \\
exchanges \\
between \\
different \\
industries \\
\end{tabular} & 0.088 & 0.136 & 0.179 & 0.149 & 0.091 & 0.319 \\
\hline & \begin{tabular}{|l|}
$\begin{array}{l}\text { Toget } \\
\text { financial } \\
\text { benefits }\end{array}$ \\
\end{tabular} & -0.249 & -0.152 & -0.169 & -0.120 & -0.014 & 0.088 \\
\hline & \begin{tabular}{|l|} 
To support \\
entrepreneurs \\
and start-ups
\end{tabular} & 0.124 & 0.243 & 0.121 & 0.253 & 0.073 & 0.073 \\
\hline & \begin{tabular}{|l|}
$\begin{array}{l}\text { To use as an } \\
\text { advertisement }\end{array}$ \\
\end{tabular} & 0.128 & 0.014 & -0.004 & -0.035 & 0.383 & 0.131 \\
\hline & \begin{tabular}{|l|} 
Request from \\
the government
\end{tabular} & 0.118 & 0.080 & 0.034 & -0.061 & -0.074 & -0.101 \\
\hline & \begin{tabular}{|l|} 
To double \\
as ouml \\
workplace \\
\end{tabular} & 0.017 & 0.020 & -0.050 & -0.018 & 0.020 & 0.092 \\
\hline
\end{tabular}

\begin{tabular}{|c|c|c|c|c|c|c|c|c|c|}
\hline \multirow{2}{*}{\multicolumn{2}{|c|}{$\neg \mathrm{P}<0.05$}} & ble5 & \multicolumn{7}{|c|}{ Reason for choosing the place } \\
\hline & & 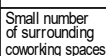 & $\begin{array}{l}\text { Large } \\
\text { number } \\
\text { of tourists }\end{array}$ & $\begin{array}{l}\text { Busy } \\
\text { pedestriar } \\
\text { praficic }\end{array}$ & $\begin{array}{l}\text { Convenien- } \\
\text { ce of trans- } \\
\text { portation }\end{array}$ & $\begin{array}{l}\text { Cheap land } \\
\text { prices }\end{array}$ & $\begin{array}{l}\text { For regional } \\
\text { revitalization }\end{array}$ & $\begin{array}{l}\text { Request fror } \\
\text { the govern- } \\
\text { ment }\end{array}$ & $\begin{array}{l}m \text { Close to the } \\
\text { respondent's } \\
\text { home }\end{array}$ \\
\hline \multirow{8}{*}{ 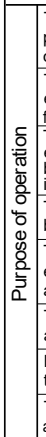 } & \begin{tabular}{|l} 
To attract \\
people from \\
outside the area
\end{tabular} & 0.223 & 0.046 & 0.180 & -0.020 & -0.075 & 0.342 & 0.081 & 0.046 \\
\hline & $\begin{array}{l}\text { To create an } \\
\text { exchange base } \\
\text { for local residents }\end{array}$ & 0.154 & 0.019 & 0.044 & -0.008 & -0.017 & 0.394 & -0.054 & -0.086 \\
\hline & $\begin{array}{l}\text { To promote } \\
\text { exchanges } \\
\text { between different } \\
\text { industries }\end{array}$ & 0.071 & 0.094 & -0.086 & -0.017 & 0.046 & 0.132 & -0.123 & 0.001 \\
\hline & \begin{tabular}{|l} 
To get financial \\
benefits
\end{tabular} & 0.031 & 0.061 & -0.006 & 0.020 & 0.047 & -0.077 & 0.014 & 0.074 \\
\hline & \begin{tabular}{|l} 
To support \\
entrepreneurs \\
and start-ups
\end{tabular} & 0.060 & 0.086 & 0.123 & 0.158 & 0.030 & 0.220 & 0.153 & -0.113 \\
\hline & 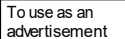 & 0.084 & 0.520 & 0.034 & -0.022 & -0.067 & 0.077 & 0.092 & 0.074 \\
\hline & \begin{tabular}{|l|}
$\begin{array}{l}\text { Request from } \\
\text { the government }\end{array}$ \\
\end{tabular} & -0.049 & 0.263 & 0.051 & -0.071 & -0.062 & 0.297 & 0.822 & -0.074 \\
\hline & $\begin{array}{l}\text { To double } \\
\text { as own workplace }\end{array}$ & 0.099 & 0.032 & -0.066 & -0.058 & 0.003 & -0.182 & -0.121 & 0.269 \\
\hline
\end{tabular}

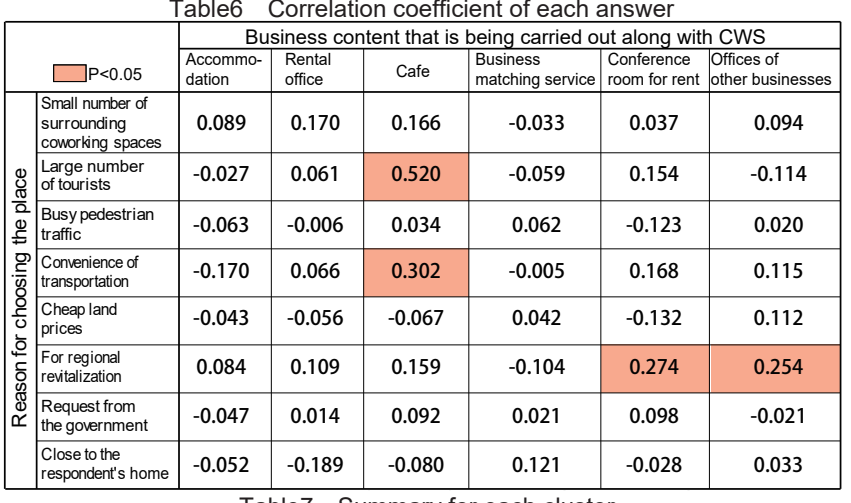

\begin{tabular}{|c|c|c|c|c|c|c|}
\hline \multirow[b]{2}{*}{$\begin{array}{l}\text { Cluster } \\
\text { No. }\end{array}$} & \multirow[b]{2}{*}{ Name } & \multirow[b]{2}{*}{ Number } & \multicolumn{2}{|c|}{ Centroid of each cluster } & \multicolumn{2}{|c|}{ Legend } \\
\hline & & & $\begin{array}{l}\text { Number of } \\
\text { seats (seats) }\end{array}$ & $\begin{array}{l}\text { Route price } \\
\left(10000 \mathrm{yen} / \mathrm{m}^{2}\right)\end{array}$ & \begin{tabular}{|l|}
$\begin{array}{l}\text { Each } \\
\text { case }\end{array}$ \\
\end{tabular} & Cent \\
\hline CL1 & Small scale / Low land price & 15 & 12.2 & 3.8 & 0 & 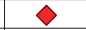 \\
\hline CL2 & Small scale / High land price & 13 & 17.6 & 56.0 & 0 & $\diamond$ \\
\hline CL3 & Medium scale / Medium land price & 18 & 35.5 & 16.3 & 0 & $\diamond$ \\
\hline CL4 & Large scale / Low land price & 19 & 55.3 & 3.4 & 0 & $\diamond$ \\
\hline CL5 & Large scale / High land price & 25 & 76.9 & 77.9 & 0 & $\diamond$ \\
\hline
\end{tabular}

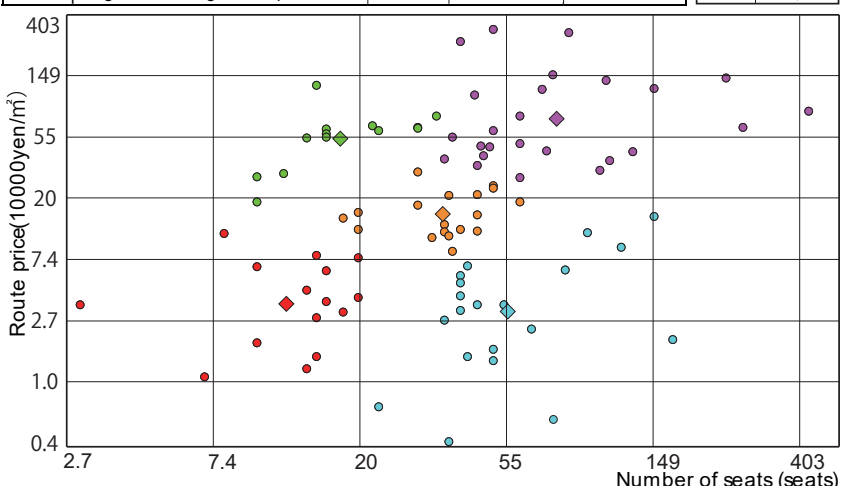

Fig.15 Number of seats and route price in each case and Cluster allocation 
・クラスター1 (小規模低地価) は、建物の所有形態は「所有」、運 営主体は「個人」、内装は「従前のまま」、場所選定の理由として「運 営者の自宅から近く」「初期費用が安い」ことを挙げ、ターゲット は「個人」としている傾向が他より強い。

・クラスター2( 小規模高地価) は、交流に関する運営方針として「日 常的に挨拶を交わす」「仕事上の知識、技術の共有、交換」「共に仕 事を遂行する」といった項目を重視していない傾向が他より強い。 ・クラスター3(中規模中地価) は、有意差が現れる項目が比較的 少なく、中庸な值をとっている。

・クラスター 4 ( 大規模低地価) は、運営範囲は「建物全体」、補助 金の活用有無では「活用している」、運営目的として「地域外から 人を呼び込むため」「地域住民の交流拠点をつくることを重視」「異 業種間の交流を促進するため」「起業家やスタートアップ企業のサ ポートのため」「行政からの依頼」を挙げ、場所選定の理由として 「周辺に CWS が少ないため」「旅行者が多いため」「地域活性化のため」 としている傾向が他より強い。

・クラスター 5 ( 大規模高地価) は、運営主体は「企業」、内装は「新 規施工」、場所選定の理由として「交通の便がいい」を挙げ、利用 者層は「金融系」「営業・販売系」「事務系」「学生」といった特定 の層である傾向が他より強い。逆に、運営目的として「地域外から 人を呼び込むため」「異業種間の交流を促進するため」「自身の仕事 場を兼衫るため」、場所選定の理由として「初期投資費用が低い」 といった項目を挙げていない傾向が他より強い。

\section{3-5. 小結}

国内 CWS ののアンケート調査により、施設、運営、計画、利用者 に関する全体的な傾向を把握し、相関分析により各回答の関連を考 察した。またクラスター分析で規模と地価による類型化を行い、類 型ごとの回答傾向に特徵があることを見出した。

\section{4. 施設利用者の利用行動特性}

\section{4-1. 調査施設の選定と概要}

前章の分析により、(5)大規模高地価クラスターでは、他に比べて

内装を新規施工している割合が高く、より運営者の意向が内部空間 に反映されていると考え、(5)大規模高地価クラスターを対象とし、 調查協力を得た 3 つ事例を抽出し調查分析を行った。尚、調查は いずれも平日の 1 日、開店時から閉店時までを対象とし、調査員は 極力利用者の行動に対して影響が小さくなり、かつ全体を見渡せる 席を選択し、観察調查を行った。

各事例の概要と調查員の位置をFig. 16〜 18 に示す。事例 1 は、 主な家具のレイアウトが一つの方向を向いていること、事例 2 は他

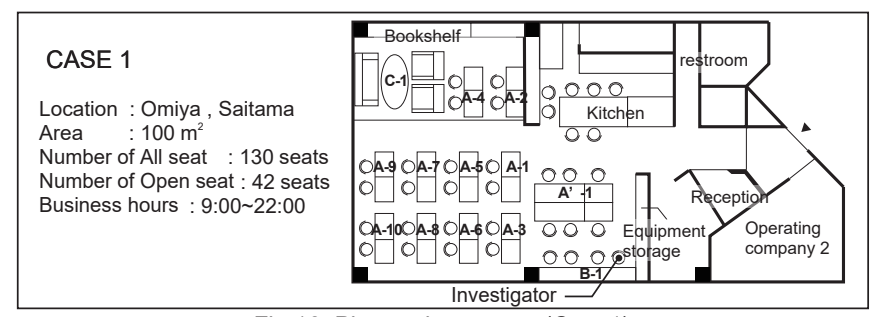

Fig.16 Plan and summary (Case1)

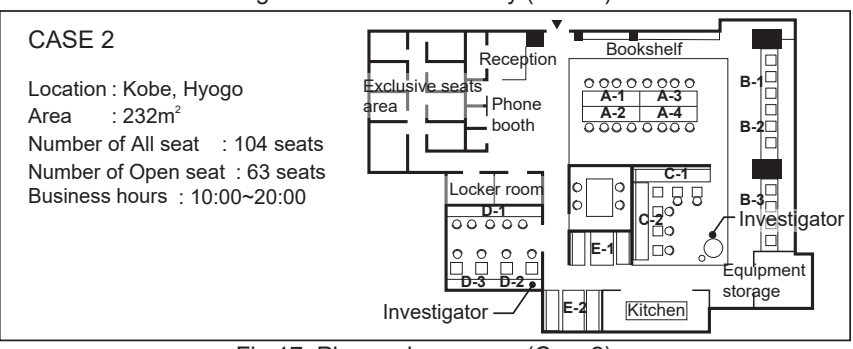

Fig.17 Plan and summary (Case2)

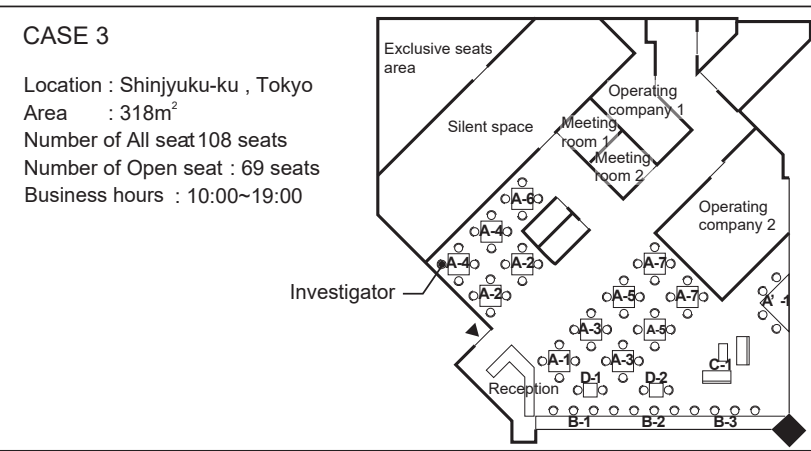

Fig 18 Plan and summary (Case 3 )

Table8 Adjusted residuals of questionnaire response for each cluster

\begin{tabular}{|c|c|c|c|c|c|c|c|c|c|c|c|c|c|c|}
\hline 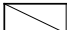 & Ownership & p of space & Scope of & f operation & & & Operating enti & & & With or with & out subsidy & & Interior & \\
\hline $\begin{array}{l}\text { Cluster } \\
\text { No. }\end{array}$ & Rent & Own & part of building & $\begin{array}{l}\text { Whole of } \\
\text { building }\end{array}$ & Company & NPO & Administration & Private & Other & With & Without & $\begin{array}{l}\text { New } \\
\text { construction }\end{array}$ & Use as it is & Both \\
\hline CL1 & -3.19 & 3.19 & 0.77 & -0.77 & -2.55 & -0.13 & 0.84 & 2.00 & 0.95 & -1.34 & 1.34 & -1.18 & 2.78 & -1.10 \\
\hline CL2 & 0.99 & -0.99 & 0.71 & -0.71 & 0.74 & 0.04 & -0.71 & -0.06 & 0.04 & -1.13 & 1.13 & -1.37 & 0.28 & 1.15 \\
\hline CL3 & -0.13 & 0.13 & 0.86 & -0.86 & -1.83 & 0.66 & 0.63 & 0.81 & 0.66 & -1.63 & 1.63 & -0.68 & -1.07 & 1.56 \\
\hline CL4 & 0.03 & -0.03 & -2.04 & 2.04 & 0.04 & 0.57 & 0.58 & -0.02 & -0.41 & 4.15 & -4.15 & 0.17 & -0.54 & 0.27 \\
\hline CL5 & 1.93 & \begin{tabular}{|c|}
-1.93 \\
\end{tabular} & -0.27 & 0.27 & 2.99 & -0.77 & -1.06 & -1.91 & -1.66 & -0.47 & 0.47 & 2.33 & -1.19 & -1.36 \\
\hline
\end{tabular}

\begin{tabular}{|c|c|c|c|c|c|c|c|c|c|c|c|c|c|c|c|c|c|c|}
\hline 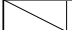 & & & & Purpos & e of operation & & & & & & & Reas & son for choos & sing the $p$ & lace and the & e proprety & & \\
\hline $\begin{array}{l}\text { Cluster } \\
\text { No. }\end{array}$ & $\begin{array}{l}\text { To attract } \\
\text { people from } \\
\text { outside the } \\
\text { area }\end{array}$ & \begin{tabular}{|l|} 
To create an \\
exchange base \\
for local \\
residents
\end{tabular} & \begin{tabular}{|l|} 
To promote \\
exchanges \\
between \\
different \\
industries \\
\end{tabular} & \begin{tabular}{|l} 
Toget \\
financial \\
benefits
\end{tabular} & \begin{tabular}{|l|} 
To support \\
entrepreneurs \\
and start-ups
\end{tabular} & $\begin{array}{l}\text { To use as an } \\
\text { advertise- } \\
\text { ment }\end{array}$ & $\begin{array}{l}\text { Request from } \\
\text { the govern- } \\
\text { ment }\end{array}$ & $\begin{array}{l}\text { To double } \\
\text { as own } \\
\text { workplace }\end{array}$ & Other & \begin{tabular}{|l} 
Small number of \\
surrounding \\
coworking \\
spaces
\end{tabular} & $\begin{array}{l}\text { Large } \\
\text { number } \\
\text { of tourists }\end{array}$ & \begin{tabular}{|l} 
Busy \\
pedestrian \\
traffic
\end{tabular} & $\begin{array}{l}\text { Convenience of } \\
\text { transportation }\end{array}$ & $\begin{array}{l}\text { Cheap land } \\
\text { prices }\end{array}$ & For regional & $\begin{array}{l}\text { Close to the } \\
\text { respondent's } \\
\text { home }\end{array}$ & $\begin{array}{l}\text { Low initial } \\
\text { investment } \\
\text { cost }\end{array}$ & Other \\
\hline $\mathrm{CL2}$ & 0.27 & -0.40 & -0.18 & 1.29 & -1.15 & 0.04 & -1.01 & 1.76 & 0.39 & -1.53 & -0.57 & 1.57 & -0.05 & 0.41 & -1.01 & 0.04 & 0.94 & 1.04 \\
\hline CL3 & 0.92 & 0.08 & -0.48 & -0.88 & 0.36 & -0.34 & -0.16 & 1.03 . & $\mid-2.30$ & -0.35 & -0.70 & 0.92 & -0.75 & -1.12 & 0.08 & -0.34 & -0.57 & -0.47 \\
\hline CL4 & 2.33 & 2.44 & 2.53 & -0.48 & 2.27 & 1.55 & 2.93 & -0.78 & 0.89 & 2.55 & 2.84 & -0.02 & 0.57 & 1.13 & 2.96 & \begin{tabular}{|l|}
-1.38 \\
\end{tabular} & -0.15 & -2.36 \\
\hline CL5 & -2.34 & $\begin{array}{l}-1.37 \\
\end{array}$ & -1.97 & 0.15 & -0.33 & -0.77 & -1.52 & -2.31 & 1.31 & -0.30 & -0.86 & -0.50 & 2.48 & -0.34 & -1.37 & -0.77 & -2.56 & 0.19 \\
\hline
\end{tabular}

\begin{tabular}{|c|c|c|c|c|c|c|c|c|c|c|c|c|c|c|c|c|}
\hline 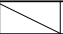 & & & lanagement po & licy for exchan & inge & & & Main targe & & & & & b type of $\mathrm{cu}$ & arrent user & & \\
\hline $\begin{array}{l}\text { Cluster } \\
\text { No. }\end{array}$ & $\begin{array}{l}\text { Daily greetings } \\
\text { between users }\end{array}$ & \begin{tabular}{|l|} 
Sharing and \\
exchanging work \\
knowedge and \\
technology \\
between users
\end{tabular} & $\begin{array}{l}\text { Do the work } \\
\text { together }\end{array}$ & $\begin{array}{l}\text { Users in various } \\
\text { occupations and } \\
\text { fields }\end{array}$ & $\begin{array}{l}\text { s Users of the } \\
\text { same occupation } \\
\text { or field }\end{array}$ & $\begin{array}{l}\text { Exchange base } \\
\text { for local } \\
\text { residents }\end{array}$ & Individual & Company & Both & $\begin{array}{l}\text { Civil } \\
\text { servant }\end{array}$ & $\begin{array}{l}\text { Interpersonal } \\
\text { service }\end{array}$ & Finance & Sales & $\begin{array}{l}\text { Office } \\
\text { work }\end{array}$ & Student & Housewife \\
\hline $\mathrm{CL} 2$ & -2.22 & -3.23 & -2.21 & 0.03 & 0.04 & -0.35 & 0.45 & -1.01 & 0.07 & -0.88 & -1.66 & -0.79 & -2.69 & -0.01 & -0.10 & -1.05 \\
\hline CL3 & 1.44 & 2.02 & 0.08 & -0.49 & -1.34 & -0.18 & -0.52 & -1.23 & 1.12 & 0.81 & 1.37 & -0.50 & 1.05 & 0.25 & 0.14 & -0.17 \\
\hline CL4 & 0.16 & 0.48 & -0.15 & 0.27 & -0.41 & 1.25 & -1.24 & -0.22 & 1.30 & -0.02 & 1.08 & -1.32 & -0.77 & -1.04 & -0.59 & -0.29 \\
\hline CL5 & -0.46 & -0.15 & 1.46 & 0.47 & 1.90 & -0.38 & -0.62 & 0.39 & 0.40 & 0.01 & 0.45 & 2.15 & 3.03 & 2.17 & 2.01 & 0.90 \\
\hline
\end{tabular}


施設と比較して間仕切りの量が多いこと、事例 $3^{3 \text { 注 }}$ 15) は間仕切りが なく、同じ机、同じ椅子が多く並んでいることが特徵である。

\section{4-2. 利用者の行動観察結果のグラフ化}

各事例の行動観察の結果を Fig. 19〜21 に示す。縦軸は Fig. 16 〜 18 中の各座席のナンバリングを示し、横軸は時刻を示している。 また、図中の数字は利用者を、英字は運営者及びスタッフを示す。

全事例共通して座席は端の方、あるいは受付から遠い方から選択 される傾向にあることがわかった。また、事例 1 と事例 2 のカウン ター席は選択されなかった。利用者同士の交流は多くは確認出来な かったが、運営者同士、または運営者と利用者による交流が確認で き、その交流のほとんどがキッチンや受付の近くで発生していた。

事例 1 は利用者の大半がパソコン作業をしているのに対し、事例 2 や事例 3 では利用者の作業内容の偏りは確認できなかった。さら に、事例 1 は席 A'-1 では短時間の打ち合わせ、A タイプの席は長 時間のパソコン作業と、座席毎で滞在時間や利用内容が異なること

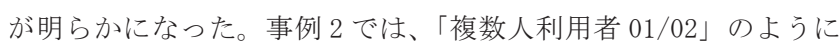
同じ席で椂々な利用をする利用者を確認できた。また、キッチンに おいてスタッフと利用者が会話する場面が見られた。事例 3 では、 席を移動する利用者 $(03 / 05 / 06 / 07)$ や、人を入れ替えながら打ち 合わせを行うといった様子（利用者 10/11/12/14）も確認できた。

\section{4-3. 各事例の利用者数、利用時間、混雑度と行動量の分析}

行動観察結果から、各利用者の滞在時間、席移動回数、移動先、 作業種類数、交流回数を読み取り、そこから最大滞在時間、最小滞 在時間、平均滞在時間、混雑度、移動頻度、外出頻度、キッチン利 用頻度、平均作業種類数、交流頻度、打ち合わせ頻度を算出した。 算出式と結果を Table9、Table10 に示す。事例 1 は利用時間が長く、 混雑度も高めだが、移動頻度、平均作業種類数、交流頻度、打ち合 わせ頻度が最も低かった。事例 2 は混雑度が最も低いが、キッチン 利用頻度が高く、交流頻度も高かった。事例 3 は滞在時間が最も短 いが、移動頻度、平均作業種類数、打ち合わせ頻度が最も高い結果 となった。

\section{5. 利用者の場所選択行為と交流行動に対する意識}

\section{5-1.インタビュー概要}

本章では各事例で行った利用者インタビュー結果を分析する。イ ンタビューは半構造化として 5 分〜 10 分程度で行った。主な質問 内容は、利用者像 (性別、年齢、職業、事務所の有無、普段の仕事 場所）、当日の利用目的、CWS を利用寸る理由、当該 CWS の選択理由、 利用頻度、現在の利用内容、座席の選択理由、他の席に対する印象、 席移動の有無と理由、他者との交流の有無とその内容、きっかけ、 理由についてである。事例 $1 、 2$ は平日及び休日、事例 3 は平日の みの営業のため平日に調查を行い、計 50 人（事例 1: 平日 $12 、$ 休 日 10、事例 2：平日 12 、休日 7、事例 3：平日 9）から回答を得た。

\section{5-2. 利用者像}

利用者の職業、事務所の有無、普段の活動場所、利用目的につい ての回答結果を示す (Fig. $22 \sim 25)$ 。平日では自営業で特定の才 フィスを持たず、主にCWS を仕事場として使用する利用者を多く確 認できた。一方で、休日では CWS を主に学習目的で使用する利用者 が増加し、さらに趣味関係で CWS を使用する利用者も現れることが わかった。つまり、CWS は会社で働く人やCWS で働く人、自営業で

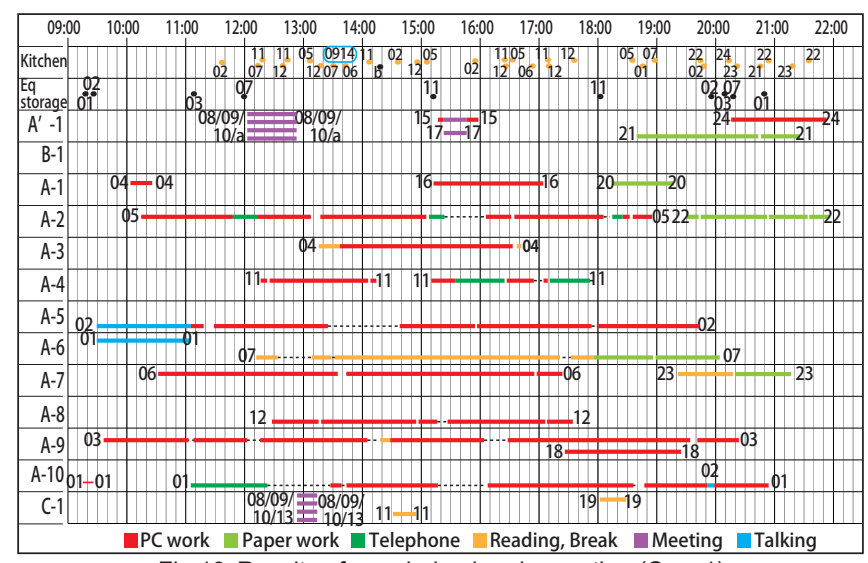
Fig.19 Results of user behavior observation (Case1)

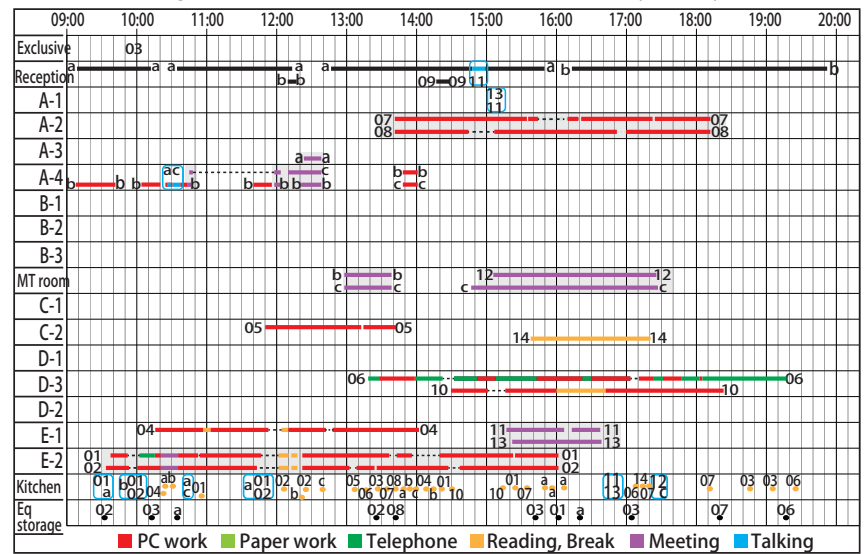

Fig.20 Results of user behavior observation (Case2)

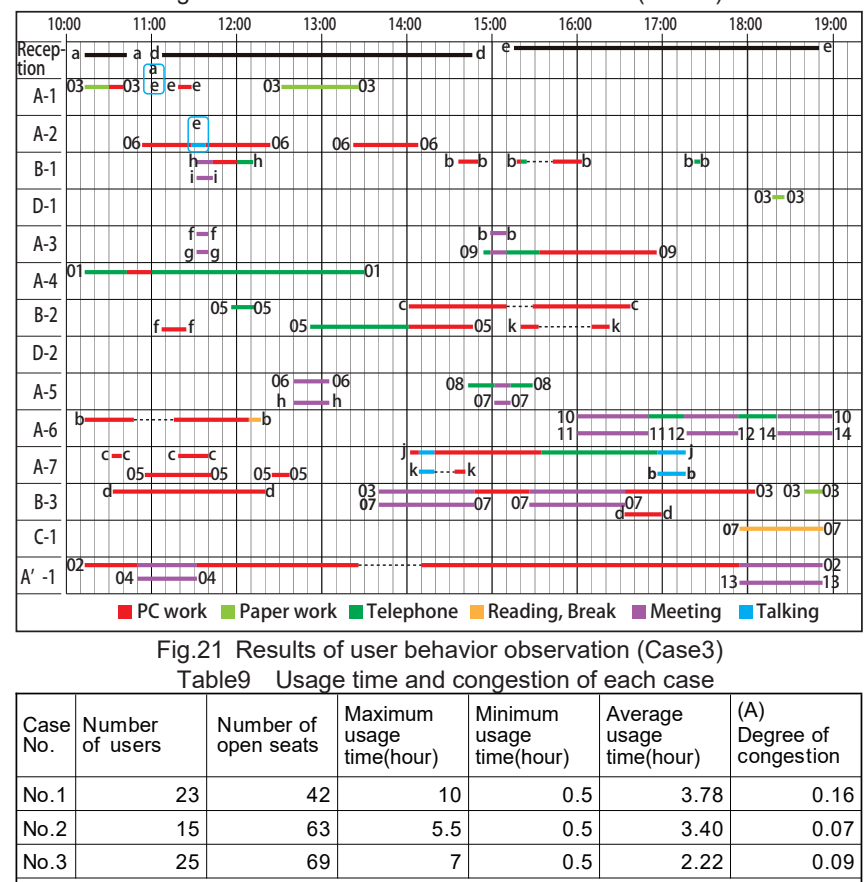

(A) $=$ Total number of times of customers moves / Business hour $\times$ Number of open seats Table10 Amount of activity of users in each case

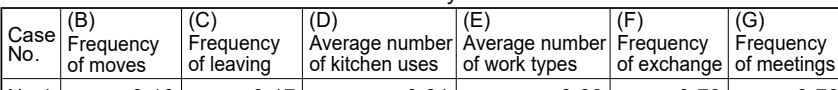
\begin{tabular}{|l|r|r|r|r|r|r|}
\hline No.1 & 0.10 & 0.17 & 0.31 & 0.39 & 0.79 & 0.79 \\
\hline No.2 & 0.29 & 0.41 & 0.82 & 0.51 & 2.35 & 1.47 \\
\hline No.3 & 0.36 & 0.21 & - & 0.76 & 1.80 & 5.41 \\
\hline
\end{tabular}

$(\mathrm{B})=$ Total number of times of customers moves / Total customer usage time

(B) = Total number of times of customers moves / Total customer usage time
(C) = Total number of times of customers leaving / Total customer usage time

(C) = Total number of times of customers leaving / Total customer usage time
(D) = Total number of times of customers using the kitchen / Total customer usage time

(D) $=$ Total number of times of customers using the kitch
(E) $=$ Number of work types/ Total customer usage time

$(E)=$ Number of work types/ Total customer usage time
$(F)=$ Total number of times of exchanges / Total customer usage time

(G) = Total number of times of meeting / Total customer usage time 
働く人の他に、学生にも利用されているが、それらの利用者像や利 用目的は平日と休日では異なると考えられる。

また、各事例の利用者の利用頻度を Tab1e 11 に示す。事例 1 は全 体の半数 $(11 / 22)$ が利用頻度が週 3 回より多いヘビーユーザーで あったのに対し、事例 2 は全体の半数以上 (12/19) で週 1 回以下、 又は初回、2 回目のライトユーザーであった。

\section{5-3. 施設の選択理由}

CWS を利用する理由、及び当該 CWS の選択理由に対する回答の録 音データ（全回答者 50 人、総抽出語数 4953 語、293 文）をテキス ト化し、ソフト ${ }^{\text {注 }}{ }^{16)}$ を用い分析を行った。尚、コワーキングーコワー

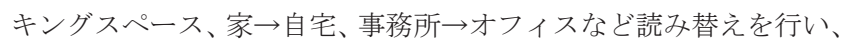
指示語についても文脈より読み取り、読み替えを行っている。

分析により頻出語上位 30 を抽出したものをTable12 に示す。CWS」 「自宅」「オフィス」「カフェ」といった場所を示寸言葉が多く登場 しており、その前後の語を見ると（Table13）、「他の」+「CWS」「自 宅」+「集中」+「できない」などがあり、他の場所との比較の中で 自分に適した環境を選択しているということが推察される。また「集 中」「作業」「静か」という語が多いことから、作業空間として適し ていると感じている利用者が多く、テレワークの拠点として活用し ていると考えられる。一方、「交流」という言葉は多く現れなかった。 更に「近い」「安い」といった地理的、経済的要因も多数出現して いる。「インテリア」と「良い」「好き」いう語の組み合わせも見ら れ、内装・家具といった要素も選択理由となっている。

\section{5-4. 座席の選択理由と他の座席の印象}

インタビュー調查で得られた、座席の選択理由、及び他の座席の 印象に関する発言のうち特徴的なものを事例ごと、座席タイプごと にまとめた。

\section{1) 事例 1(Fig.26)}

通常テーブル席の奥や端では、「PC 画面を見られたくない」「壁 際が落ち着く」「優先的に選択する」、大テーブル席では「グループ 作業」「話をするところ」、カウンター席は「一人用」「集中すると ころ」「長時間には向かない」、ソファ席は「気分転換」「ラフな打 合せをするところ」という回答が得られた。

\section{2) 事例 2(Fig.27)}

エリア 1 は「開放感がある」「勉強時に使う」、エリア 2 は「人人 のとき」「集中できる」「奥まっていて落ち着く」、゙ックス席は「グ ループ作業」「一人で使うのは悪い」「テリトリーがはっきりしてい
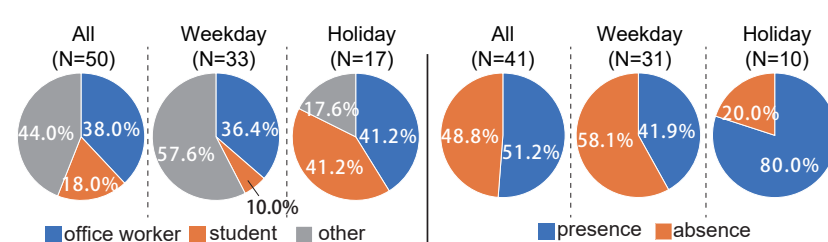

affice worker $\square$ student $\square$ other

Fig.22 Occupations of users in all cases Fig.23 Presence or absence of

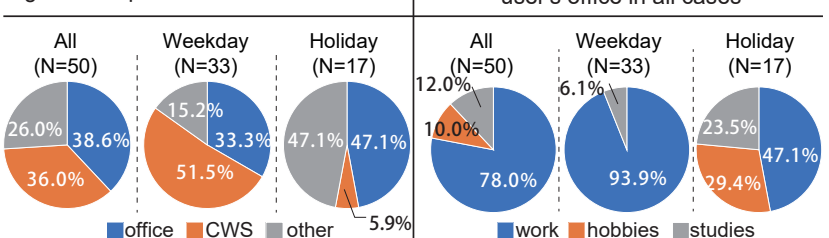

Fig.24 User's usual activity place in all cases Fig.25 Purpose of use of users in all cases
Table11 Frequency of use of each case

\begin{tabular}{|l|r||l|l|r|r|}
\hline $\begin{array}{l}\text { Case } \\
\text { No. }\end{array}$ & $\begin{array}{l}\text { Number of } \\
\text { respondents }\end{array}$ & No answer & $\begin{array}{l}\text { No more than once } \\
\text { a week or 1st time, } \\
\text { 2nd time }\end{array}$ & 2 or 3 times a week & $\begin{array}{l}\text { More than 3 times } \\
\text { a week }\end{array}$ \\
\hline No.1 & 22 & 0 & 6 & 5 & 11 \\
\hline No.2 & 19 & 1 & 12 & 2 & 4 \\
\hline No.3 & 9 & 3 & 1 & 3 & 2 \\
\hline
\end{tabular}

Table12 Frequently answered words for reasons for choosing a facility

\begin{tabular}{|c|c|c|c|c|c|}
\hline $\begin{array}{l}\text { 抽出語 } \\
\text { Extracted words }\end{array}$ & \begin{tabular}{|l|} 
出現回数 \\
Number of \\
appearances
\end{tabular} & \begin{tabular}{|l} 
抽出語 \\
Extracted words
\end{tabular} & \begin{tabular}{|l|} 
出現回数 \\
Number of \\
appearances
\end{tabular} & $\begin{array}{l}\text { 抽出語 } \\
\text { Extracted words }\end{array}$ & $\begin{array}{l}\text { 出現回数 } \\
\text { Number of } \\
\text { appearances }\end{array}$ \\
\hline $\begin{array}{l}\text { コワーキングスペース } \\
\text { coworking space }\end{array}$ & 36 & \begin{tabular}{|l|} 
思う \\
feel
\end{tabular} & 18 & \begin{tabular}{|l} 
感じ \\
impression
\end{tabular} & 10 \\
\hline $\begin{array}{l}\text { 自宅 } \\
\text { home }\end{array}$ & 36 & $\begin{array}{l}\text { 他 } \\
\text { other }\end{array}$ & 18 & $\begin{array}{l}\text { 環境 } \\
\text { environment }\end{array}$ & 10 \\
\hline $\begin{array}{l}\text { 使う } \\
\text { use }\end{array}$ & 35 & $\begin{array}{l}\text { 近い } \\
\text { near }\end{array}$ & 17 & $\begin{array}{l}\text { インテリア } \\
\text { interior }\end{array}$ & 9 \\
\hline $\begin{array}{l}\text { オフィス } \\
\text { office }\end{array}$ & 30 & \begin{tabular}{|l|} 
安い \\
cheap
\end{tabular} & 15 & $\begin{array}{l}\text { 利用 } \\
\text { use }\end{array}$ & 9 \\
\hline $\begin{array}{l}\text { 集中 } \\
\text { concentration }\end{array}$ & 27 & \begin{tabular}{|l|} 
自分 \\
oneself
\end{tabular} & 14 & \begin{tabular}{|l} 
一番 \\
best
\end{tabular} & 8 \\
\hline $\begin{array}{l}\text { 場所 } \\
\text { place }\end{array}$ & 26 & \begin{tabular}{|l|} 
多い \\
many
\end{tabular} & 14 & $\begin{array}{l}\text { 行< } \\
\text { go }\end{array}$ & 8 \\
\hline $\begin{array}{l}\text { 仕事 } \\
\text { work }\end{array}$ & 23 & $\begin{array}{l}\text { 大宮 } \\
\text { Omiya }\end{array}$ & 13 & \begin{tabular}{|l|} 
借りる \\
rent
\end{tabular} & 8 \\
\hline \begin{tabular}{|l|} 
良い \\
good
\end{tabular} & 21 & $\begin{array}{l}\text { 料金 } \\
\text { price }\end{array}$ & 13 & \begin{tabular}{|l} 
雾囲気 \\
atmosphere
\end{tabular} & 8 \\
\hline $\begin{array}{l}\text { カフェ } \\
\text { cafe }\end{array}$ & 20 & $\begin{array}{l}\text { 静か } \\
\text { quiet }\end{array}$ & 11 & & \\
\hline people & 20 & \begin{tabular}{|l|} 
無い \\
nothing
\end{tabular} & 11 & & \\
\hline $\begin{array}{l}\text { 作業 } \\
\text { operation }\end{array}$ & 18 & $\begin{array}{l}\text { 来る } \\
\text { come }\end{array}$ & 11 & $\begin{array}{l}\text { 交流 } \\
\text { exchange }\end{array}$ & 4 \\
\hline
\end{tabular}

Table13 Number of combinations of words in the same sentence

\begin{tabular}{|c|c|c|c|}
\hline \multicolumn{2}{|c|}{$\begin{array}{l}\text { Key word (Number } \\
\text { of appearances) }\end{array}$} & \multirow[t]{2}{*}{ combinated words } & \multirow{2}{*}{\begin{tabular}{|r|}
$\begin{array}{l}\text { Number of } \\
\text { appearances }\end{array}$ \\
13
\end{tabular}} \\
\hline "CWS」 & (36) & & \\
\hline $\begin{array}{l}\text { 「自宅」 } \\
\text { "home" }\end{array}$ & (36) & $\begin{array}{l}\text { 「集中」+「できない」 or 「欠く」 or 「より」+「できる」 } \\
\text { "concentration" + "cannot" or "lack" or "than" + "can" }\end{array}$ & 10 \\
\hline \multirow{3}{*}{$\begin{array}{l}\text { 「カフェ」 } \\
\text { "cafe" }\end{array}$} & \multirow{3}{*}{ (20) } & $\begin{array}{l}\text { 「長居」 or 「長い時間」 or 「一日中」 } \\
\text { "long stay" or "long time" or "all the day" }\end{array}$ & 5 \\
\hline & & $\begin{array}{l}\text { 「がやがや」 or「うるさい」 or「より」+「静か」 } \\
\text { "noisy" or "than" + "quietly" }\end{array}$ & 5 \\
\hline & & $\begin{array}{l}\text { 「料金」 or「安い」 } \\
\text { "fee" or "inexpensive" } \\
\end{array}$ & 5 \\
\hline \multicolumn{2}{|c|}{$\begin{array}{l}\text { 「インテリア」 } \\
\text { "interior" }\end{array}$} & $\begin{array}{l}\text { 「良い」 or 「好き」 } \\
\text { "good" or "like" }\end{array}$ & 6 \\
\hline
\end{tabular}

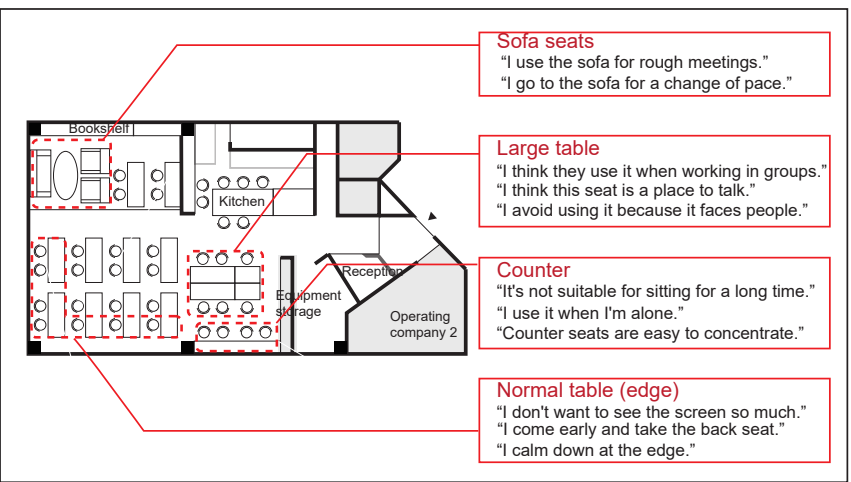

Fig.26 Reasons for seat selection by weekday users (Case 1)

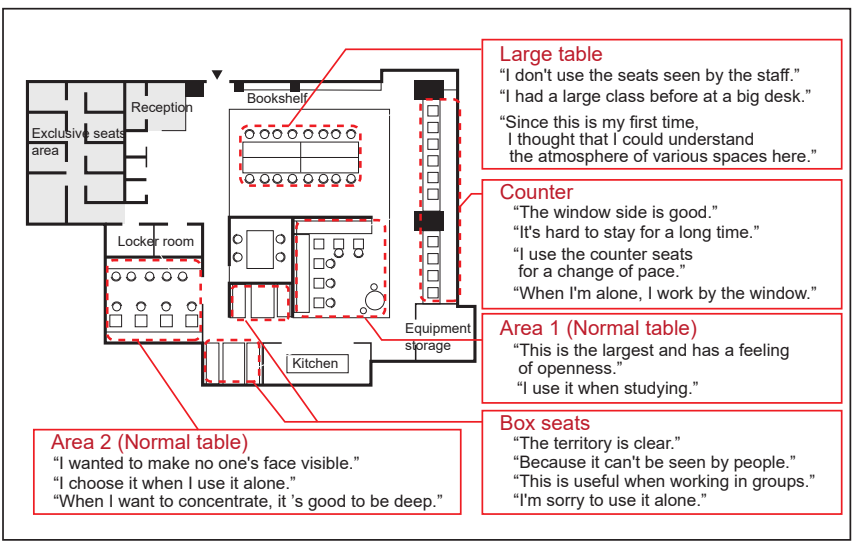

Fig.27 Reasons for seat selection by weekday users (Case 2) 
る」「人から見られない」大テーブル席は「大人数でのイベントの とき」「受付から見られる」「全体の雰囲気がわかる」、カウンター 席は「気分転換」「一人用」「長時間は向かない」という言及があった。

\section{3) 事例 3(Fig.28)}

通常テーブル席の端側は「静か」「気が楽」、中央部では「目立つ」「う るさくなる」あるいは「人がたくさん通って挨拶できる」というよ うに、同じの席タイプでも位置によって異なる印象や利用を確認で きた。カウンター席では「外を見る」「集中する」、ソファ席は「リ ラックス」「会話する」という特徽があった。

\section{4)まとめ}

総じて、大テーブルは大人数やグループで話をするところ、カウ ンター席は一人で短時間、気分転換や集中するときに利用、また外 部に面する外を見られる、ソファ席は、複数人で打ち合わせや、リ ラックスをするところ、という認識がなされていた。

空間単位では、部屋の端や囲われた空間が、落ち着き集中しやす く作業に適しているという回答が多く、逆に、部屋の中央や大テー ブル席は、全体が把握しやすく人目に付きやすいため、初めての利 用や交流を目的にする場合に選択される傾向があった。

また、事例や座席タイプによらず他者の存在に対する言及が多く、 他者との関係の中で、自分の居場所を見出している様子が明らかと なった。

\section{5-5. 席移動の有無と理由 (Table14)}

席移動の有無と理由についての質問に対する回答を示す。「1日 の間で席移動がある」という回答が全体の約半数であり、その理由 は「作業内容を変える」「気分転換」「集中寸るため」であった。

5-6. 交流の有無と内容、きっかけ、理由（Table15、16）

他者との交流の有無と内容、きっかけ、理由についての質問に対 する回答を示す。事例 $1 、 2$ に関しては半数以上で「交流がない」 と回答があり、「交流を望んでいない」「他者が交流する䨌囲気でな い」という理由から、対象施設を個々の作業場として捉えている利 用者が多い結果となった。また事例 2 では、「利用が間もないため 交流がない」「交流してみたい」という回答も一定数得られた。一 方で、事例 3 は「交流がある」との回答が多数であり、内容も「挨 摱程度」ではなく「知識や情報の共有を行う」「ともに仕事を遂行 する」といった協㗢、共創の空間として捉えているものであった。尚、 交流するきっかけは、総じて運営者の紹介が最も多く、イベント・ セミナーといった回答も複数得られた。

\section{5-7. 利用者の意識と行動の関係}

4 章の行動観察結果と合わせ考察を行う。

作業に関して、発生頻度は異なるものの、3 事例とも作業内容を 変える際や気分転換のために席を変えるという様子や意識が見ら れ、近年のオフィスで見られるABW (Activity Based Working) と同 様の使われ方がなされていることが確認された。自宅やオフィスの 代わりとして利用するという回答も多く、テレワークの拠点として 認識されていることが明らかとなった。

一方、交流に関しては事例ごとに異なる特徵が見られた。

事例 1 は、利用頻度が高く滞在時間も長いへビーユーザーが多数 いるが、活動の種類や施設内での移動が少なく、交流を求めていな い作業目的の利用者で客層が固定化されてしまっていることで、よ り交流が発生しにくい䨌囲気を作りだしていると考えられる。
事例 2 も交流がない利用者が多かったが、混雑度が最も低かった ことから他者と交流する機会事体が少ないと言え、また利用頻度の 少ないライトユーザーが多いことも交流が少ない原因の一つと考え られる。また、キッチン周りでの短時間の交流が多くみられ、交流 を生むきっかけとなる場所として機能している一方で、間仕切りに より空間が細分化されていることで他者と出会うきっかけが少なく なっていると考えられる。

事例 3 は、平均滞在時間が最も短かったが、運営側が積極的に自 らの仕事で利用したり、利用者と交流したりして、また利用者・運 営者とも席移動や活動内容の変化を頻繁に起こすことで他者と接す る機会が増え、深度の深い交流が起こっていると考えられる。

以上から、利用者の利用頻度や行動特性・交流意欲により作られ る場の䨌囲気、運営者の利用や介入、キッチンや受付といった交流 のきっかけとなる場所の有無、空間の適度な開かれ具合、が相互に 関係し交流の頻度・深度に影響を与えている、と考察した。

またインタビュー調查を通して、他の場所や他者の存在に関する 言及が多いことから、他の場所と比較の中で、また他者の影響を受 けながら、自らに適した環境を選択・構築していると考えられる。

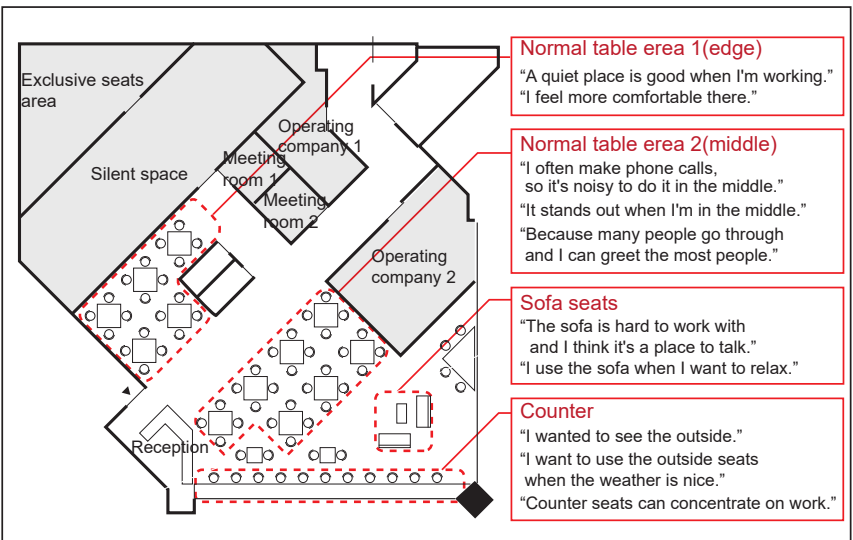

Fig.28 Reasons for seat selection by weekday users (Case 3) Table14 Reasons to move seats

\begin{tabular}{|c|c|c|c|c|c|c|c|c|}
\hline \multirow{2}{*}{$\begin{array}{l}\text { Case } \\
\text { No. }\end{array}$} & \multirow{2}{*}{$\begin{array}{l}\text { Weekday } \\
\text { or } \\
\text { Holiday }\end{array}$} & \multirow{2}{*}{\begin{tabular}{|l|} 
Number of \\
respondents
\end{tabular}} & \multicolumn{2}{|l|}{ Move seat } & \multicolumn{4}{|c|}{ Reason } \\
\hline & & & Yes & & $\begin{array}{l}\text { Change the work } \\
\text { content }\end{array}$ & Change of pace & $\begin{array}{l}\text { Want to } \\
\text { concentrate }\end{array}$ & \\
\hline \multirow{2}{*}{ No.1 } & Weekday & 12 & & 7 & 5 & 2 & & 0 \\
\hline & Holiday & 10 & & 4 & 2 & 1 & & 1 \\
\hline \multirow{2}{*}{ №.2 } & Weekday & 12 & & 4 & 2 & 2 & & 0 \\
\hline & Holiday & 7 & & 5 & 4 & 1 & & 0 \\
\hline No. 3 & Weekday & 9 & & 6 & 2 & 2 & & 2 \\
\hline
\end{tabular}

Table15 Number of people with no exchanging and reason

\begin{tabular}{|c|c|c|c|c|c|c|c|c|c|}
\hline \multirow[b]{2}{*}{$\begin{array}{l}\text { Case } \\
\text { No. }\end{array}$} & \multirow[b]{2}{*}{$\begin{array}{l}\text { Weekday } \\
\text { or } \\
\text { Holiday }\end{array}$} & \multirow[b]{2}{*}{$\left|\begin{array}{l}\text { Number of } \\
\text { respondents }\end{array}\right|$} & \multirow[b]{2}{*}{$\begin{array}{l}\text { Have no } \\
\text { Exchange }\end{array}$} & \multicolumn{6}{|c|}{ Reason } \\
\hline & & & & $\begin{array}{l}\text { No need } \\
\text { want to } \\
\text { concentrat }\end{array}$ & $\begin{array}{l}\text { Not an } \\
\text { atmosphere } \\
\text { to exchange }\end{array}$ & \begin{tabular}{|l|} 
No \\
opportunity
\end{tabular} & $\begin{array}{l}\text { Shortly after } \\
\text { the start of } \\
\text { use }\end{array}$ & $\begin{array}{l}\text { Want to } \\
\text { exchange }\end{array}$ & Other \\
\hline \multirow{2}{*}{ No.1 } & Weekday & 12 & 9 & 2 & 5 & 2 & 2 & 0 & 1 \\
\hline & Holiday & 10 & 10 & 4 & 2 & 2 & 1 & 2 & 1 \\
\hline \multirow{2}{*}{ No. 2} & Weekday & 12 & 9 & 4 & 3 & 1 & 4 & 2 & 1 \\
\hline & Holiday & 7 & 4 & 0 & 2 & 0 & 1 & 2 & 1 \\
\hline No.3 & Weekday & 9 & 3 & 2 & 0 & 0 & 1 & 0 & 0 \\
\hline
\end{tabular}

Table16 Number of people with exchanging, opportunity and depth

\begin{tabular}{|c|c|c|c|c|c|c|c|c|c|c|}
\hline \multirow[b]{2}{*}{$\begin{array}{l}\text { Case } \\
\text { No. }\end{array}$} & \multirow{2}{*}{$\begin{array}{l}\text { Weekday } \\
\text { or } \\
\text { Holiday }\end{array}$} & \multirow[b]{2}{*}{$\begin{array}{l}\text { Number of } \\
\text { respondents }\end{array}$} & \multirow[b]{2}{*}{$\begin{array}{l}\text { Have } \\
\text { Exchange }\end{array}$} & \multicolumn{3}{|c|}{ opportunity } & \multicolumn{4}{|c|}{ depth } \\
\hline & & & & $\begin{array}{l}\text { Introduction } \\
\text { by the } \\
\text { operator }\end{array}$ & $\begin{array}{l}\text { Event/ } \\
\text { Seminar }\end{array}$ & Other & $\begin{array}{l}\text { Exchange } \\
\text { greetings }\end{array}$ & $\begin{array}{l}\text { Exchange } \\
\text { knowledge }\end{array}$ & $\mid \begin{array}{l}\text { Work } \\
\text { together }\end{array}$ & \begin{tabular}{|l} 
No \\
answer
\end{tabular} \\
\hline \multirow{2}{*}{ No.1 } & Weekday & 12 & 3 & 1 & 1 & 1 & 2 & 0 & 0 & 1 \\
\hline & Holiday & 10 & 0 & 0 & 0 & 0 & 0 & 0 & 0 & 0 \\
\hline \multirow{2}{*}{ No.2 } & Weekday & 12 & 3 & 0 & 1 & 2 & 2 & 0 & 0 & 1 \\
\hline & Holiday & 7 & 3 & 1 & 1 & 1 & 1 & 1 & 0 & 1 \\
\hline No.3 & Weekday & 9 & 6 & 4 & 1 & 1 & 0 & 3 & 3 & 0 \\
\hline
\end{tabular}




\section{6. 運営者の意識からみる CWS の更新プロセス}

\section{6-1. 運営者によるCWS の更新プロセスのモデル化}

本章では運営者に対しての半構造化インタビューを結果を基に分 析を行う。主な質問事項を Table17 に示す。インタビューは 25 分 〜 35 分程度で行い、録音データをテキスト化し、事例 1 から 3240 字、事例 2 から 5142 字、事例 3 から 4965 字のテキストデータを得た。 その内容を質的研究で広く採用されている $\mathrm{M}^{-} \mathrm{GTA}^{16)}{ }^{12}$ 注) の手続きを 参考に分析を行った。尚、本研究ではデータの範囲に関する方法論 的限定を調查協力を得た 3 事例で行っている点に留意しつつ、以下 言及する。

インタビューデータから、16の概念を生成し、各概念を 7 つの カテゴリーへと束ねた。概念の定義とカテゴリーの関係を Table18 に示す。更にカテゴリー間の関係性を示し、運営者の CWS の更新プ ロセスについてのモデル化を行った結果図をFig. 29 に示し、この 図のストーリーラインを下記に示す。尚、カテゴリーを【】、概念 を〈〉、具体例内の言葉を「」で示している。

【運営と担当の経緯】「コワーキングスペースという」「新しい働き 方」に〈所属団体の CWS への興味〉があり、その団体の中で〈適 任者として選ばれた〉運営者が、

【運営する意味】〈他施設との比較〉しながら、あるいは〈地域一 の貢献〉などの意味を見出し、

【理想と想定】〈交流を重視した場所づくり〉を理想とし、〈利用者 の想定〉を行い運営を始めたが、

【運営の実態と課題】運営を進めると〈交流を望まない利用者もい た〉り、〈運営上のレイアウトの課題〉があること、

【気づきと葛藤】〈理想・想定と実態の乘離〉やCWS のニーズや価值 を〈やってみて気づき〉、その理想と実態の中で〈悩みながら運営〉し、

【金銭面】〈補助金制度の活用〉を狙うことを契機としたり、〈事業 採算性との兼㸚合い〉を考慮に入れながら、

【理想と実態に答える更新案】〈ニーズを踏まえたレイアウト変更〉 や、〈利用者を繋げるシステム構築〉を行い、時には〈バランスを とりつつ運営者が介入〉するなどして、

CWS の更新を行っていくプロセスが読み取れた。

\section{6-2. 各施設のレイアウト、システム更新の具体例}

運営者インタビューにより、各施設ともレイアウトやシステムを 更新（または検討）していることが分かった。6-1. で記した CWS の更新の具体例として記す。

事例 1(Fig. 30) は、開設当初は交流空間としての運用を狙ってお りテーブルを対面式レイアウトとしていたが、作業場としてのニー ズが高かったため、一方向型レイアウトへの变更や集中スペースを 設けるなどの改修を行い、利用率の向上に繋げている。また利用者 属性と利用時間を把握するシステムを組み交流を生むきっかけを作 ろうとしていたが、補助金が出なかったために頓挫した経緯がある。 事例 2 は、レイアウト変更は行わないが、会員登録システムをア プリで管理して交流を促すシステムを開発し、運用を開始している。

事例 3 (Fig. 31) は調査後補助金を契機に改修を行っており、当初 は事例を参考にサイレントスペースを設けていたが、予測よりも需 要がなかったことと、より交流を重視させたいという運営者の意図 から、サイレントスペースを廃止し、また様々な活動に対応させる ため席タイプを増やす方針でレイアウト更新を行っている。
Table17 Question matters

Position of the operator in the organization / Background of operation / Aim of creating a place / Impression of space / Aim and actual use as an exchange space / Aim and actual use as a work space / Presence or absence of interation between operator and use / user attribute / business profibiliy / Presence or absence of subsidy / reference facility

Table18 Definition of concept and relationship between concept and category

\begin{tabular}{|c|c|c|}
\hline $\begin{array}{l}\text { (カテゴリー】 } \\
\text { Category }\end{array}$ & 〈概念〉 Concept & 定義 Definition \\
\hline \multirow{2}{*}{$\mid \begin{array}{l}\text { 【運賞炎担当 } \\
\text { History of operation } \\
\text { and charge }\end{array}$} & \begin{tabular}{|l|} 
〈所属団体の CWS への興味〉 \\
Interest in CWS of affiliated organization
\end{tabular} & $\begin{array}{l}\text { lWSの存在を知る } \\
\text { Know the existence of CWS }\end{array}$ \\
\hline & \begin{tabular}{|l} 
〈適任者として選ばれる〉 \\
Selected as the person
\end{tabular} & $\begin{array}{l}\text { 経緯に即した理由で運営者になるる } \\
\text { Become an operator for a reason } \\
\text { that suits the circumstances }\end{array}$ \\
\hline \multirow{2}{*}{$\begin{array}{l}\text { 【運営する意味】 } \\
\text { Meaning of } \\
\text { operation }\end{array}$} & $\begin{array}{l}\langle\text { 〈他施設との比較〉 } \\
\text { Comparison with other facilities }\end{array}$ & $\begin{array}{l}\text { 他施設を例示しながら自施設の特徵を考える゙ } \\
\text { Consider the characteristics of your own facily } \\
\text { while exemplifying other facilities }\end{array}$ \\
\hline & \begin{tabular}{|l}
$\langle$ 地域への貢献〉 \\
Contribution to the community
\end{tabular} & $\begin{array}{l}\text { 自施設の地域へ還元する姿勢をもつ } \\
\text { Have an attitude to give back to the area of your facility }\end{array}$ \\
\hline \multirow{2}{*}{$\begin{array}{l}\text { 【理想と想定】 } \\
\text { Ideasumed }\end{array}$} & $\begin{array}{l}\text { 〈交流を重視した場所づくり〉 } \\
\text { Creating place that } \\
\text { emphasizes exchanging }\end{array}$ & $\begin{array}{l}\text { 交流が生まれる場所を作りたいという思い } \\
\text { exc idea of creating a place where }\end{array}$ \\
\hline & \begin{tabular}{|l}
$\mid$ |利用者の想定〉 \\
User assumption
\end{tabular} & $\begin{array}{l}\text { 利用者のターゲットを想定していた } \\
\text { Assuming user target }\end{array}$ \\
\hline \multirow{2}{*}{$\begin{array}{l}\text { 【運賞の題】態 } \\
\text { Actual conditions } \\
\text { and issues of } \\
\text { operation }\end{array}$} & $\begin{array}{l}\text { 〈交流を望まない利用者もいる〉 } \\
\text { Existence of users } \\
\text { who do not want to exchange }\end{array}$ & $\begin{array}{l}\text { 交流を望む人とそゔでない人がいる実態 } \\
\text { The reality that some people want to exchange } \\
\text { and others do not }\end{array}$ \\
\hline & 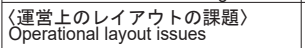 & 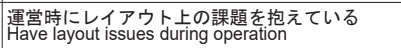 \\
\hline \multirow{3}{*}{$\begin{array}{l}\text { 【理想と寁態に } \\
\text { 悹】 } \\
\text { Renewal plan } \\
\text { that responds to } \\
\text { ideals and reality }\end{array}$} & $\begin{array}{l}\text { 〈二ーズと理想荾踏まえた } \\
\text { Lイ予〉 } \\
\text { Layout change based on needs }\end{array}$ & 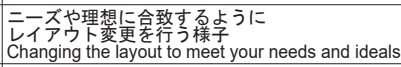 \\
\hline & $\begin{array}{l}\text { 〈利用者を繫げるシズテム構築〉 } \\
\text { System construction } \\
\text { that connects users }\end{array}$ & 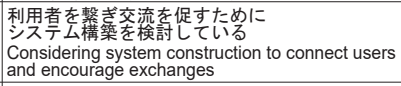 \\
\hline & $\begin{array}{l}\langle\text { 〈゙ランスをとりつつ } \\
\text { 運営者がイ〉 } \\
\text { Operator intervention } \\
\text { while balancing }\end{array}$ & 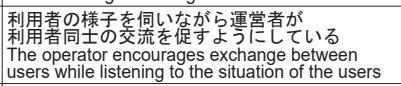 \\
\hline \multirow{3}{*}{$\begin{array}{l}\text { 【気づきと葛藤】 } \\
\text { Awarenentlict } \\
\text { and conflict }\end{array}$} & 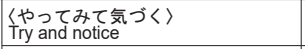 & $\begin{array}{l}\text { 運営する中で気づいたニーズや価値 } \\
\text { Needs and values that Inoticed during operation }\end{array}$ \\
\hline & $\begin{array}{l}\text { 〈理想 / 想定と実態の乘離〉 } \\
\text { Dilociation betwen ideal } \\
\text { / assumption and reality }\end{array}$ & 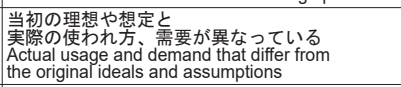 \\
\hline & 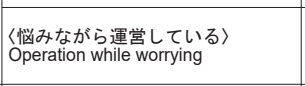 & 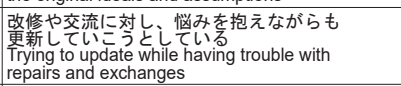 \\
\hline \multirow{2}{*}{$\begin{array}{l}\text { 【金銭面】 } \\
\text { Final side }\end{array}$} & $\begin{array}{l}\text { 〈補助金制度の活用〉 } \\
\text { Utilization of subsidy system }\end{array}$ & $\begin{array}{l}\text { 行政が設定した補助金を活用した(しょうとした) } \\
\text { Utilized (tried) the subsidy set by the government }\end{array}$ \\
\hline & \begin{tabular}{|l} 
事業採算性との兼ね合い〉 \\
Balance with busitess profitability
\end{tabular} & \begin{tabular}{|l|} 
事業採算を考慮した運営計画をしている \\
Operation plans
\end{tabular} \\
\hline
\end{tabular}

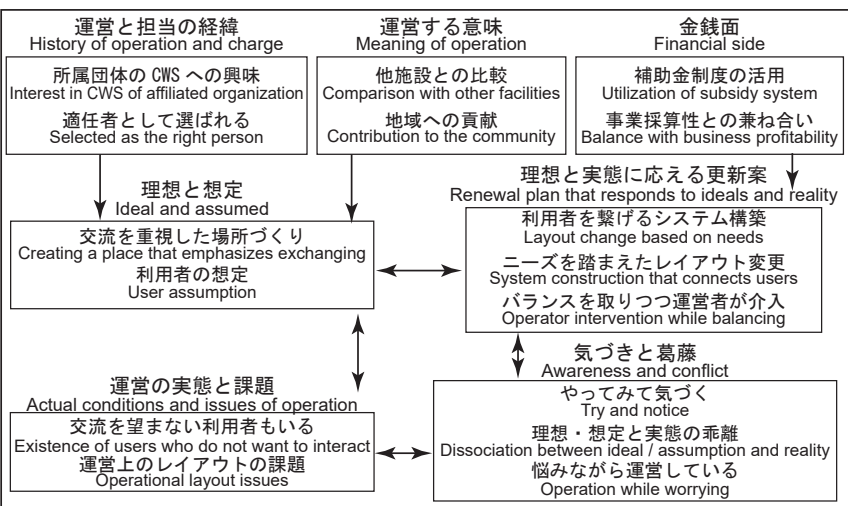

Fig.29 Modeling the operator's CWS update process with M-GTA

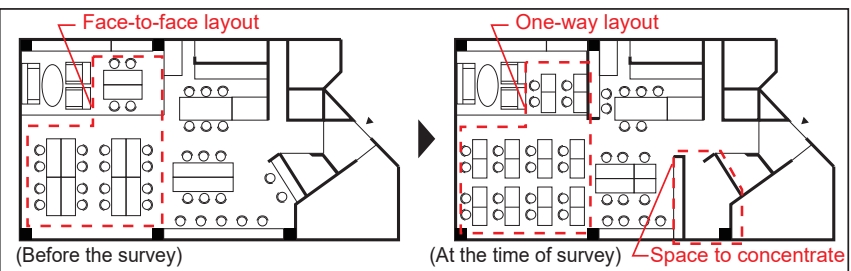

Fig.30 Layout update (Case1)

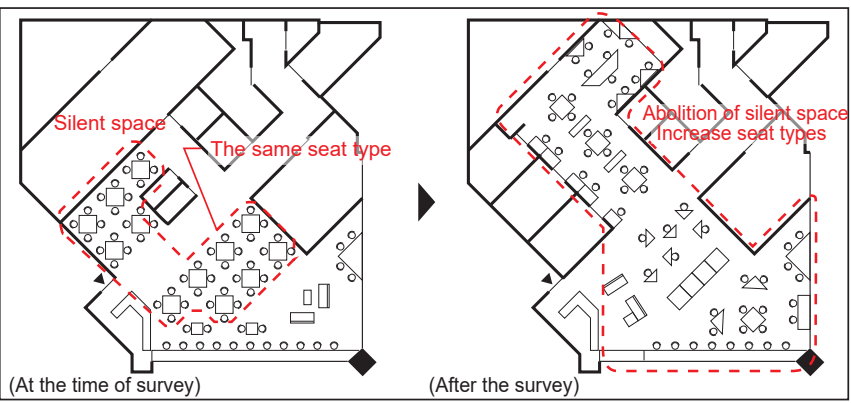

Fig.31 Layout update (Case3) 


\section{7-1. 結論}

本研究では、全国の CWS に対しての施設アンケート調査により施 設の概要、運営方針、計画内容、利用者属性について基礎的なデー タを得るとともに、規模・地価によって類型化を行い、「小規模低 地価」と「大規模高地価」で建物所有形態、経営母体、初期投資費 用などに有意差が見られること、「小規模高地価」では交流を重視 していないこと、「大規模低地価」では地域活性化の拠点を目指し ていること、など回答に特徴が見られることを明らかにした。

また、「大規模高地価」クラスターから選定した施設で利用者の 行動観察・インタビュー調査と、運営者へのインタビュー調査を行っ た。「大規模高地価」クラスターでは、利用者が自らに適した場所 を他の場所との比較の中で選択し、また他者との関係を気にしつつ 自らの場所を構築している様子を捉えた。更に、利用者の特性や意 識によって CWS の雰囲気が左右され、交流の生じや寸さに影響を与 えていることを示した。一方運営者は、利用者のニーズを踏まえ、 自らの理想との間で葛藤しながらも、施設のレイアウトやシステム を更新し、理想やニーズに答えた CWS を作り上げていく、という過 程を明らかにした。

レイアウトに関しては、家具の種類やエリア分けによって多様な 活動を生じていることが明らかとなった。特に、隔てや間仕切りで 空間を小分けにすることで、作業に適した集中しやすい空間を作る ことが出来る一方で、人が見えないことから交流を阻害する要因と なる可能性があると考えられる。またキッチンや受付といったス ペースが交流のきっかけとなることが分かった。

CWS は近年の社会情勢の変化に伴って生まれた比較的新しい空間 であることから、利用者・運営者共に模索しながら、また相互に関 係しあって場を作り上げていることが、特徴であるといえる。

\section{7-2. 今後の課題}

一方で、本研究は「大規模高地価」クラスターに限定した中から 施設を抽出し実地調查としたことから、具体的な利用者の活動内容 や、運営者による施設更新方針は事例ごとで異なる結果となった。 また、交流行動が活発でない事例もあり、CWS の意義から離れてし まっている現状も確認された。

本調查における課題としては、アンケート調查に座席数が「120 $<\mathrm{n} 」$ の施設が含まれなかったこと、利用者行動調査、インタビュー 調査の日程が限られていたことにより、日や矅日による差について 考察出来なかったこと、運営者インタビューの M-GTAによる分析は あくまでも今回の調査の範囲内で導き出した運営者像であるため、 CWS 全体の一般化された運営者像を捉えることが出来たと言い切れ ない点が挙げられる。

この先、今回調査施設におけるレイアウト・システム更新前後で の利用実態の複数日・曜日による調查により運営者の意図との関係 に更に迫ること、「大規模高地価」クラスターでの他の調查事例を 増やし、平面計画や付帯設備、家具レイアウトなどと利用者活動内 容・運営方針との関係の分析や、運営者インタビュー事例を増やし、 より一般化された運営者像を導き出すこと、「大規模低地価」など 立地・規模の異なるクラスターを対象とし利用者像・運営者の意識 の違いを論じることで、より CWS の施設計画に示唆を与えることが 出来ると考えており、今後の課題とする。
ご多用な中、調査にご協力いただいた運営者及び利用者の方々に、 記して感謝の意を表します。

\section{参考文献}

1) Nobuyuki NOMURA, Kazuhiko NISHIDE: STUDY OF SHARED OFFICE IN TERMS OF SPACE SHARING (1) Behavior observation of users around public space, Journal of JOS, Vol.4 No.2, Technical Report, pp.59-67, 2012.10 (in Japanese)

納村信之，西出和彦：空間共用からみたシェアード・オフィスの研究 （1）共用スペースを中心とした利用者の行動観察，日本オフィス学会 誌 Vol. 4 No. 2，技術報告，pp. 59-67，2012.10

2) Nobuyuki NOMURA, Kazuhiko NISHIDE: STUDY OF SHARED OFFICE IN TERMS OF SPACE SHARING (2) Observation about the change of users activity due to the change from fixed tables to movable tables in public meeting space, Journal of JOS, Vol.5 No.1, Technical Report, pp.72-77, 2013.4 (in Japanese)

納村信之，西出和彦：空間共用からみたシェアード・オフィスの研究 （2）共用ミーティングスペースにおける固定テーブルから可動テーブ ルへの変更に伴う利用状況の変化に関する考察, 日本オフィス学会誌 Vol. 5 No. 1，技術報告，pp. 72-77，2013.4

3) Tadashi UDA, Tomokazu ABE: Kyouyu/Kyousou Gata work space no Jittai Chosa: 2016 Nendo Chosa no Gaiyo Hokoku, The annals of Research Center for Economic and Business Networks, 6, bulletin (article), pp.113-143, 2017.3 (in Japanese)

宇田忠司，阿部智和：共有・共創型ワークスペースの実態調査：2016 年度調查の概要報告, 地域経済経営ネットワーク研究センター年報, pp. 113-143，2017.3

4) Tomokazu ABE, Tadashi UDA: Overview of the Correlation Analysis on Shared and Co-creating Spaces in Japan, Economic Studies, 67(1), bulletin (article), pp.109-146, 2017.6 (in Japanese)

阿部智和，宇田忠司：共有・共創型ワークスペースの実態調査：2016 年度調査の分析結果，經濟學研究，67(1), pp. 109-146, 2017.6

5) Masaaki ARIMOTO, Naoto MATSUMOTO, Yuji MATSUMOTO, Nagisa KIDOSAKI, Ryusuke NAKA: A Study on Workplace for Coworking Part1, Summaries of Technical Papers of Annual Meeting, Architectural Institute of Japan, Architectural Planning and Design, pp.331-332, 2012.7 (in Japanese)

有元政晃, 松本直人, 松本裕司, 城戸崎和佐, 仲隆介：コワーキン グに着目したワークプレイスに関する研究 (その 1 )一コワーキング の基礎的実態把握一, 日本建築学会大会学術講演梗概集, 建築計画, pp. 331-332, 2012.7

6) Shuji WATANABE, Naoto MATSUMOTo, Yuji MATSUmoto, Nagisa KIDOSAKI, Ryusuke NAKA: A Study on Workplace for Coworking Part2, Summaries of Technical Papers of Annual Meeting, Architectural Institute of Japan, Architectural Planning and Design, pp.333-334, 2012.7 (in Japanese)

渡辺修司，松本直人，松本裕司，城戸崎和佐，仲隆介：コワーキン グに着目したワークプレイスに関する研究（その 2) 一コワーキングス ペース利用者の場所選択要因に関する考察一, 日本建築学会大会学術講 演梗概集，建築計画， pp. 333-334, 2012.7

7) Kotaro TSUJII, Yuta IWASAKI, Hirotaka SAWADA, Yuji MATUMOTO, Ryusuke NAKA: CONSIDERATION ABOUT THE TREND CHANGE OF CO-WORKING IN JAPAN VALUE AND PROBLEM OF THE CO-WORKING FOR COMPANY, Journal of JOS, Vol.10 No.1, Research Paper, pp.25-29, 2018.4 (in Japanese) 辻井耕太郎, 岩崎裕太, 澤田博貴, 松本裕司, 仲隆介：日本におけ るコワーキングの様態変化に関する考察 企業におけるコワーキング の価值と課題, 日本オフィス学会誌, Vol10 No. 1, 研究論文, pp. 2529, 2018. 4

8) Yusaku FURUUCHI, Ryuji KATSUMATA, Masako MUROTA: Study on actual situation and business achievement of co-working space - Case study of the metropolis and 3 prefectures of capital area, Reports of City Planning Institute of Japan, No.15, pp.333-336, 2017.02 (in Japanese) 
古内優作, 勝俣竜治, 室田昌子：コワーキングスペースの運営実態と 運営成果に関する研究 一一都三県を対象として一, 公益社団法人日 本都市計画学会 都市計画報告集, No. 15, pp. 333-336, 2017.2

9) Yuko MIKI, Koichi MIWA, Naoko KURIYAMA: Study on Community Formation of Coworking Space: Relations between Users and Involvement with the Community, AIJ Kinki chapter research meeting, No.55, pp.497-500, 2015.6 (in Japanese)

三木優子, 三輪康一, 栗山尚子：コワーキングスペースのコミュニ ティ形成に関する研究 利用者間および地域との関わりに着目して, 日 本建築学会近畿支部研究報告集 55, 計画系, pp. 497-500, 2015.6

10) Tomoyuki IKEDA, Shigeru MATSUMURA: Utilization of the coworking space in rural areas -A Case Study of Yamagata Murayama region-, The 17th Japan Telework Society conference proceedings, pp.21-24, 2015 (in Japanese)

池田知之，松村茂：地方におけるコワーキングスペース利活用に関す る研究〜山形村山地域を事例に〜, 第 17 回日本テレワーク学会研究発 表大会予稿集，pp. 21-24，2015

11) Shigeru MATSUMURA: A study on the management challenges of the co-working space in rural areas -A Case Study of Yamagata Murayama region-, The 17th Japan Telework Society conference proceedings, pp.25-30, 2015 (in Japanese)

松村茂：地方におけるコワーキングスペースの運営課題に関する考察 〜山形村山地域を事例に〜 , 第 17 回日本テレワーク学会研究発表大会 予稿集, pp. 25-30, 2015

12) Tadashi UDA: A Theoretical Study on Coworking, 63(1), bulletin (article), pp.115-125, 2013.6 (in Japanese)

宇田忠司：コワーキングの概念規定と理論的展望, 經濟學研究, 63(1), pp. 115-125, 2013.6

13) Kenta HIRAMOTO, Tomokazu ABE, Tadashi UDA: 〈Kakenhi Symposium〉 Workstyle to Chiiki Community no Tenbou, Coworking kara Kangaeru, The Annals of Research Center for Economic and Business Networks, 3, pp.53-58, 2014.3 (in Japanese) 平本健太, 阿部智和, 宇田忠司：〈科研費シンポジウム>ワーク・ス タイルと地域コミュニティの展望, コワーキングから考える, 地域経 済経営ネットワーク研究センター年報， 3, pp. 53-58, 2014.3

14) Kohei KOBAYASHI, Koichi MIWA, Naoko KURIYAMA: Study on community formation of Share-space : from the viewpoint of management solutionan and spatial composition of coworking space, AIJ Kinki chapter research meeting, No.52, pp.501-504, 2012.5 (in Japanese)

小林鋼平, 三輪康一, 栗山尚子：シェア空間のコミュニティ形成に関 する研究： coworking スペースの運営方法と空間構成に着目して, 日 本建築学会近畿支部研究報告集 52, 計画系, pp. 501-504, 2012.5

15) Kyo SATANI, Kenichi NAKAYA, Yutaka FUJIKI: Tsunagari no Shigotojutsu "Coworking" wo Hajimeyou, yosensha, 2012 (in Japanese)

佐谷恭, 中谷健一, 藤木穣：つながりの仕事術「コワーキング」を始 めよう, 洋泉社, 2012

16) Yasuhito KINOSHITA: Grounded Theory Approach no Jissen, Koubundou, 2003 (in Japanese)

木下康仁：グラウンデッド・セオリー・アプローチの実践, 弘文堂, 2003

注

注 1）コワーキングに関する情報サイトで、海外の情報も掲載されている (http://wiki.coworking.com/w/page/16583831/FrontPage)

注 2）コワーキング共同組合 (https://www.coworking.coop/about/coworking/)

注 3)「CoworkingJAPAN」日本全国の CWS を評判や特徵、設備で検索でき るサイト。(https://co-co-po.com/)

注 4）送付数は 853 であったが、配布後、閉鎖や運営終了が確認されたもの、 及び本文に記載の対象空間に該当する空間が存在しないと回答があっ た 115 施設を除いた数である。

注 5）会議室や固定席、シェアオフィスなどは含まれない。

注 6）オープン席に加え会議室や固定席、シェアオフィスなどを含み、さら に運営している他事業の席も含めた席数のことを指寸。

注 7）予備調查によって、CWS を含むレンタルオフィス・サービスオフィス 等の運営を主な事業内容としている運営会社が、全体席数「120<n」 である施設を複数運営していることを確認しているが、本研究におい ては、調査時の対象リストに入っていなかったため、または対象りス 卜内であるが回答がなかったために上記運営会社による施設は確認さ れなかった。

注 8）一般財団法人資産評価システム研究センターが提供する全国地価マッ プ (https://www.chikamap.jp/chikamap/Portal?mid=216) による各 地点の 2019 年の固定資産税路線価を用いた。

注 9）株式会社エスミ MAC 多変量解析 ver. 3.0 を使用。

注 10）相関係数を $\mathrm{r}$ とし、 $0.9<|\mathrm{r}| \leqq 1$ は完全な相関がある、 $0.7 \leqq|r|$ $\leqq 0.9$ は強い相関がある、 $0.4 \leqq|\mathrm{r}|<0.7$ は相関がある、0.2 $|r|<0.4$ は弱い相関がある、 $0.0<|r|<0.2$ はほとんど相関がな いとして扱う。

注 11）注 9）同様、株式会社エスミ MAC 多変量解析 ver. 3.0 を使用。サン プル間の距離計算： 原データのユークリッド距離、クラスター間の 距離計算：ウォード法、クラスター数：5、重心周辺クラスターを生 成する、といら条件で分析を行った。

注 12）路線価、席数とも最大、最小で析数の差が大きいため、低を e とした 対数処理を行った数值を用いてクラスター分析を行った。

注 13）注 7) に記載の通り全体席数「120<n」の施設が多数あり、実際の分 布においては「特大規模」クラスターが生成される可能性があるが、 本調査を基にした分析では生成されなかった。

注 14）サンプルサイズによるばらつきを考慮に入れた上で、個別の回答項目 に有意差があるかを分析する手法。下式参照。尚、調整済み残差 $\mathrm{D}_{\mathrm{i} j}$ は標準正規分布に従う。

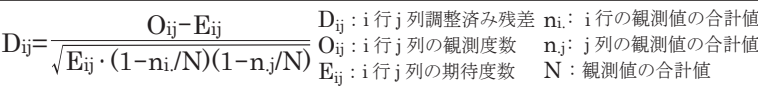

注 15）事例 3(case3) におけるサイレントスペース（silent space）及び、会 議室 (meeting room) は、本研究におけるCWS の対象範囲内ではある が、調查員を配することが出来ないため上記室内の行動記録は行って いない。

注 16）文章型データを統計的に分析するためのソフトウェアである「KH coder 3」を分析に用いた。

注 17) インタビューデータから概念、複数の概念をまとめたカテゴリーを生 成し、その関係を解䣋的にまとめ、最終的に結果図とストーリーライ ンを描くことによって分析テーマのプロセスを明らかにするものであ る。著者によれば、「グラウンデッド・セオリー・アプローチの場合 には分析者の判断によって対象者を選択寸る」ため「「このデータの 範囲に関する限り」という限定化を行う」とされている。また、「デー 夕の収集と分析の同時並行性」として「分析の進展に応じてデータ の範囲を拡大寸ることもあれば、逆に収集したデー夕にさらに限定 を加えて絞り込むことも起きてくる」「最初にまとめて収集したデー 夕（ベースデータ）と分析経過に基づき追加収集されたデータ（追加 データ）の二段階に分けて進める」とされており、今後追加調查によ りデータの範囲を拡大する余地がある。また、ベースデータの数量に ついても「グラウンデッド・セオリー・アプローチは度数による分析 ではないので、対象者の数が最低何人必要かという問題はない」とし ながらも「大体の目安としては 10 例から 20 例くらい」とされている ため、本研究では手法を「参考に」分析を行っている。 


\title{
STUDY ON ACTUAL USAGE AND FACILITY MANAGEMENT OF COWORKING SPACE
}

Understanding facility characteristics and focusing on the relationship between user awareness / behavior and operator management policy

\author{
Taku IMAIZUMI ${ }^{* 1}$, HiroshiSATO ${ }^{* 2}$, Kyoko IKUTA *3 \\ and Kazuhisa TSUNEKAWA *4 \\ ${ }^{1}$ Grad. Student, Graduate School of Environmental Studies, Nagoya Univ. \\ ${ }^{2}$ Coelacanth and Associates Co., Ltd. \\ ${ }^{3}$ Prof., Dept. of Architecture, Science and Engineering, Meijo Univ., Dr.Eng. \\ ${ }^{* 4}$ Prof., Graduate School of Engineering, Nagoya Univ., Dr.Eng.
}

In recent years, due to changes in social conditions such as "development of ICT environment" and "work style reform", the number of workers who are not bound by the framework of places and organizations is increasing, and coworking spaces are increasing as places where those people work. The coworking space is not just about sharing the place to work but it is characterized by sharing wisdom and information and creating value by exchanging information, but since there are few previous studies. Therefore, the research is conducted with the aim of using it as a basic material for future facility planners and operators to plan and operate coworking spaces.

First, by conducting a questionnaire survey of domestic coworking spaces, we grasp basic data on facilities, operations, plans, and users, analyze the correlation of each answer, and analyze the relationship between operation policy, exchange policy, location, and the business they are doing together. In addition, we clarify that five clusters are generated by cluster analysis with scale and land price as variables, and each cluster is characterized by the response tendency such as building ownership, operating entity, initial investment cost, user base, operating purpose, and exchange policy.

Next, three facilities were selected from the cluster named "Large-scale high land price type", and behavior observation surveys and interview surveys were conducted with users. From behavioral observations and interview surveys with users, users select the place by comparing it with other places, and build it as a place suitable for themselves by continuing to use that place while paying attention to the relationship with others. It was used to move seats when the user changed the work content or changed his mood. It turned out that many people use it as a substitute for their home or office, and it is recognized as a base for telework. In addition, it is considered that the exchange between users is brought about by the mutual relationship between the users' willingness to interact, the intervention of the operator, the appropriate replacement of people, and the place that triggers them.

In addition, we conducted an interview survey with the operators of similar facilities. The interview survey with the operator was analyzed with reference to the M-GTA method. The process that the operator selected as the right person in the affiliated organization updates the layout and system of the facility while gaining awareness and conflict while operating based on his ideals and the needs of the users was clarified and shown with specific update cases.

From the above, we have shown the process of creating a new space, a coworking space, in which users and operators interact with each other at this research facility. In the future, we think that it will be possible to discuss the differences between the image of users and the image of operators by increasing the number of survey cases, such as targeting different clusters.

(2021 年 2 月 9 日原稿受理, 2021 年 7 月 6 日採用決定) 